\title{
Isolation and manipulation of protoplasts from the unicellular green alga Penium margaritaceum
}

\author{
Sandra Cristina Raimundo ${ }^{1 *}$, Iben Sørensen², Berke Tinaz ${ }^{1,3}$, Eleanore Ritter ${ }^{1}$, Jocelyn K. C. Rose ${ }^{2}$ \\ and David S. Domozych ${ }^{1}$
}

\begin{abstract}
Background: The unicellular charophycean green alga Penium margaritaceum has emerged as an appealing experimental organism in plant cell wall and cell biology research. Innovative practical approaches in the manipulation and maintenance of this unicellular model alga are needed in order to probe the complexities of its subcellular and molecular machinery. Protoplast isolation and manipulation expedites a new range of experimental possibilities for Penium-based studies. These include enhanced means of isolation of subcellular components and macromolecules, application of intracellular probes for high resolution microscopy of live cells, transformation studies and analysis of the fundamental mechanisms of plant cell expansion and wall polymer deposition.
\end{abstract}

Results: We present a methodology for enzyme-based digestion of the Penium cell wall and the isolation of protoplasts. The subcellular events associated with this technology are presented using multiple microscopy-based techniques. We also provide protocols for applying an array of intracellular dyes that can be used as markers for specific organelles and membrane microdomains in live cells. Finally, we present a protocol for the purification of a nuclei-rich fraction from protoplasts, which can be used for the isolation of nuclear DNA.

Conclusion: Protoplast isolation, culturing and manipulation provide valuable means for molecular and cellular studies of Penium. The protocol described here offers a rapid and effective mechanism for fast and effective production of protoplasts. Subsequently, the protoplasts may be used for microscopy-based studies of specific subcellular components and the isolation of organelles and nuclear DNA. These methods offer a new practical methodology for future studies of this model organism in cell and molecular biology.

Keywords: Protoplasts, Cellulase, Pectate lyase, Penium margaritaceum, Nuclei isolation, Intracellular markers, Lipid domains

\section{Background}

Penium margaritaceum (Zygnematophyceae; Streptophyta) is a unicellular green alga that belongs to the charophycean green algae (CGA), or basal Streptophyta [1-3], i.e., the assemblage of extant green algae most closely related and ancestral to land plants $[4,5]$. This species has become increasingly valuable as a tool for studies of the primary cell wall of plants [6-9]. Penium

\footnotetext{
*Correspondence: sraimund@skidmore.edu

1 Department of Biology, and Skidmore Microscopy Imaging Center,

Skidmore College, Saratoga Springs, NY 12866, USA

Full list of author information is available at the end of the article
}

has a simple geometric form consisting of an elongate cylinder with rounded edges, and produces only a primary cell wall that contains several of the polymers that are typically found in the cell walls of land plants, namely cellulose, pectins (homogalacturonan (HG) and rhamnogalacturonan I (RGI)) and proteoglycans [10, 11]. Secretion of cell wall material is focused at specific loci at the cell surface and may be conveniently monitored in live cells using cytochemical labeling protocols [12]. Penium engages an elaborate endomembrane apparatus and membrane trafficking network to "deposit" polymers into the growing cell wall, as well as to secrete an 
extracellular gel required for gliding motility and ultimate ensheathment onto a surface [6,13-15]. Specific subcellular events associated with these processes may be studied via high throughput screening of exogenous agents, such as cell wall synthesis inhibitors or cell wall degrading enzymes. Finally, recent molecular investigations [16] are providing new insights and creating opportunities for studying Penium as a model for plant cell physiology, development and evolution. All of these features make Penium an outstanding experimental system in plant cell biology $[17,18]$.

The elucidation of the structure and function of specific subcellular components and their coordinated interactions during the dynamics of cell development represent a fundamental goal in plant cell biology. Various types of biochemical, molecular and microscopy-based technologies have been used, often in correlative studies in order to elucidate such subcellular phenomena. Ever since Hanstein, in 1880 [19], first used the term protoplast to describe the plasmolyzed content of a cell enclosed by the plasma membrane, and the possibility of removing the cell wall from a cell [19], protoplast isolation and manipulation have become important methodologies in plant cell research. The cell wall is a resilient barrier to many subcellular studies, but if removed from the cell, protoplasts can be released and maintained under carefully defined conditions. During this time, diverse biochemical and molecular manipulations can be performed that are difficult, if not impossible, to do for walled cells and tissues. Many of these protoplast isolation protocols have contributed significantly to the areas of transformation and genetic engineering, somatic hybridization, organelle isolation, as well as cell wall dynamics $[20,21]$. Protoplast isolation from a charophyte was first reported nearly 4 decades ago $[22,23]$. However, since that time, very limited studies of charophyte protoplasts have been described. As Penium and other charophytes emerge as important organisms in plant cell studies, a re-investment of research in protoplast isolation, culturing and manipulation is pertinent.

In this study, we describe methods for the isolation and culturing of protoplasts from Penium. Using both fluorescent cytochemical labeling and transmission electron microscopy (TEM) imaging, we document the stages of protoplast formation and the selective removal of the pectic domain of the cell wall. We also provide methods in which the protoplasts can be employed for studying organelle structure and function, membrane trafficking and plasma membrane microdomains. Finally, we describe an optimized protocol for efficiently recovering pure fractions of nuclei from protoplasts, free from cell debris and plastid DNA, which can be used for subsequent molecular procedures, such as DNA isolation prior to genomic sequencing.

\section{Methods \\ Algal culture}

Penium margaritaceum Brébisson (Skidmore College Algal Culture Collection) was maintained in sterile liquid cultures of Woods Hole medium (see below for reference) supplemented with soil extract (WHS), $\mathrm{pH} 7.2$ at $18 \pm 2{ }^{\circ} \mathrm{C}$ in a photoperiod of $16 \mathrm{~h}$ light/ $8 \mathrm{~h}$ dark with $74 \mu \mathrm{mol}$ photons $\mathrm{m}^{-2} \mathrm{~s}^{-1}$ Photosynthetic Photon Flux of cool white fluorescent light. The cells were subcultured every week and cells from log-phase culture (7-day old cultures) were used for the procedures. WHS medium [24] (see www.marine.csiro.au/microalgae/methods/ Media\%20CMARC\%20recipes.htm\#MBL for preparation instructions) was prepared by adding $20 \mathrm{~mL} / \mathrm{L}$ of soil water extract [25] to the medium before autoclaving at $120{ }^{\circ} \mathrm{C}, 15 \mathrm{lb} / \mathrm{in}^{2}{ }^{2}(15 \mathrm{psi}$ ) for $20 \mathrm{~min}$.

\section{Protoplast isolation}

Cells were collected in $50 \mathrm{~mL}$ Falcon tubes and centrifuged for $1 \mathrm{~min}$ at $1000 \times g$. The supernatant was discarded and the cell pellet was resuspended in fresh WHS, vortexed vigorously for $30 \mathrm{~s}$ and recentrifuged. This washing step was repeated three times. It is important to wash Penium cells in order to remove the extracellular polysaccharide (EPS) or gel, which can otherwise interfere with the enzymatic digestion of the cell wall. The washed cells were incubated in $5 \mathrm{~mL}$ of a protoplast buffer (PB) $\left(0.5 \mathrm{M}\right.$ mannitol, $0.02 \mathrm{M} \mathrm{CaCl}_{2}$ in WHS, pH 7.2 filter sterilized with a $0.22 \mu \mathrm{m}$ syringe filter) on a laboratory rotator with gentle shaking for $20 \mathrm{~min}$ at room temperature (RT). The cells were centrifuged at $1000 \times g$ for $1 \mathrm{~min}$, the supernatant was discarded, and the sample was resuspended in $3 \mathrm{~mL}$ of $0.22 \mu \mathrm{m}$ filter sterilized protoplast enzyme solution (PES): $150 \mathrm{U}$ cellulase from Trichoderma reesei (\# C8546, Sigma-Aldrich, St. Louis, MO, USA), $56 \mathrm{U}$ pectate lyase (PL) from Aspergillus sp. (\# E-PCLYAN Megazyme, Bray, Ireland) in $3 \mathrm{~mL}$ of PB. The cell suspension was placed in a $30 \times 15 \mathrm{~mm}$ sterile plastic petri dish, and incubated with constant gentle shaking at RT for $2 \mathrm{~h}$. Normally, $90 \%$ of the cells release protoplasts within $2-3 \mathrm{~h}$. The progress of protoplast formation was monitored using an Olympus IX-70 inverted microscope. Once sufficient protoplasts were obtained, the suspension was aseptically poured into a sterile $15 \mathrm{~mL}$ Falcon tube and centrifuged at $70 \times g$ for $30 \mathrm{~s}$. The supernatant was discarded, the pellet containing the protoplasts was gently resuspended in $2 \mathrm{~mL}$ of $\mathrm{PB}$, and recentrifuged. This washing step was repeated twice and the supernatant discarded. Cell wall debris and cells that did not 
release the protoplast can be filtered from the protoplasts using a $40 \mu \mathrm{m}$ nylon mesh cell strainer (Thermo Fisher Scientific, Waltham, MA, USA). The pellet containing the protoplasts can be used immediately for experiments but may also be stored at $4{ }^{\circ} \mathrm{C}$ for $12 \mathrm{~h}$, or on ice for up to $48 \mathrm{~h}$. The same procedure was also performed using the following enzymes: $150 \mathrm{U}$ cellulase from $T$. reesei (\# C8546, Sigma-Aldrich, St. Louis, MO, USA) and $5 \mu \mathrm{L} /$ $\mathrm{mL}$ RGI-lyase from Cellvibrio japonicus (\# CjRgI11A, NZYTech, Lisboa, Portugal) or $12 \mathrm{U} \beta$-galactosidase from Aspergillus niger (\# E-BGLAN, Megazyme, Bray, Ireland), or $4.5 \mathrm{U} \alpha$-rhamnosidase (\# E-RHAMS, Megazyme, Bray, Ireland), or $0.6 \mathrm{U}$ endo-1,5- $\alpha$-L-arabinanase from $A$. niger (\# E-EARAB, Megazyme, Bray, Ireland), or $1.2 \mathrm{U} \alpha-1-$ arabinofuranosidase from $A$. niger (\# E-AFASE, Megazyme, Bray, Ireland), at pH 6 and pH 7.2.

\section{Chelator treatment of live cells}

Cells were collected by centrifugation at $1000 \times g$ for $1 \mathrm{~min}$. The supernatant was discarded, and after washed $3 \times$ with deionized water, the cells were incubated in $20 \mathrm{mM}$ ethylenediaminetetraacetic acid (EDTA), pH 6.0 for $20 \mathrm{~min}$ in the dark, with gentle rotation. Cells were washed with deionized water $3 \times$ before immunolabeling or cryofixation for TEM or placed in WHS under regular growth conditions for recovery studies.

\section{Intracellular dyes}

Live cells were washed $3 \times$ with fresh WHS as described above and incubated in distilled water with $4.4 \mu \mathrm{M} 5(6)$ CFDA (5,6-carboxyfluorescein diacetate) for $15 \mathrm{~min}$, 1.6 $\mu$ M BCECF AM (2',7'-bis-(2-carboxyethyl)-5,6-carboxyfluorescein, acetoxymethyl ester) for $15 \mathrm{~min}, 1.7 \mu \mathrm{M}$ DiOC6(3) (3,3'-dihexyloxacarbocyanine iodide), $2 \mu \mathrm{M}$ Lyso Tracker ${ }^{\mathrm{TM}}$ Red, $1.25 \mu \mathrm{M}$ Yeast Vacuole Membrane marker MDY-64, $2 \mu \mathrm{M}$ BODIPY ${ }^{\mathrm{TM}}$ FL C5-Ceramide (n-(4,4-difluoro-5,7-dimethyl-4-bora- $3 \alpha, 4 \alpha$-diaza-sindacene-3-pentanoyl) sphingosine), $2 \mu \mathrm{M}$ BODIPY $^{\mathrm{TM}} \mathrm{FL}$ $\mathrm{C}_{11}$-Phosphocholine (1,2-bis-(4,4-difluoro-5,7-dimethyl-4-bora-3 $\alpha, 4 \alpha$-diaza-s-indacene-3-undecanoyl)-snglycero-3-phosphocholine), and $3 \mu \mathrm{M}$ Di-4-ANEPPDHQ (aminonaphthylethenylpyridinium) (Molecular Probes ${ }^{\circledR}$, Eugene OR, USA) for $30 \mathrm{~min}$ in the dark with constant rotation, and washed $3 \times$ with distilled water. Observation with $1.6 \mu \mathrm{M} \mathrm{FM}^{\mathrm{TM}} 1$-43 ( $N$-(3-triethylammoniumpropyl)4-(4-(dibutylamino) styryl) pyridinium dibromide) in distilled water was performed immediately from min 1 to min 60 after adding the dye. Incubations for protoplasts were performed similarly, but using $\mathrm{PB}$ as incubating medium.

\section{Transmission electron microscopy (TEM)}

Cells/protoplasts/EDTA-treated cells were harvested at different time points after incubation in PES, washed $3 \times$ with $\mathrm{PB}$, and spray frozen in liquid propane cooled with liquid nitrogen [26]. Samples were freeze substituted at $-80{ }^{\circ} \mathrm{C}$ for $48 \mathrm{~h}$ in $0.5 \%(\mathrm{w} / \mathrm{v})$ glurataldehyde and $1 \%(\mathrm{w} / \mathrm{v})$ osmium tetroxide (EMS, Hatfield, PA, USA) in anhydrous acetone. After a cooling period of $2 \mathrm{~h}$ at $-20{ }^{\circ} \mathrm{C}, 2 \mathrm{~h}$ at $4{ }^{\circ} \mathrm{C}$ and $1 \mathrm{~h}$ at $\mathrm{RT}$, samples were washed with acetone and dehydrated in a graded series of acetone:Spurr's Low Viscosity embedding media (EMS, Hatfield, PA, USA) of 3:1 and 1:1 at RT for $1 \mathrm{~h}$ each. An overnight incubation with 1:3 acetone:Spurr's was performed, and a final incubation with $100 \%$ (v/v) Spurr's was performed for $12 \mathrm{~h}$ before placing the samples in BEEM $^{\circledR}$ embedding capsules (EMS, Hatfield, PA, USA). Polymerization of the plastic was performed at $70{ }^{\circ} \mathrm{C}$ for $8 \mathrm{~h}$. Samples were sectioned with a Leica EM UC6 ultramicrotome (Leica Microsystems, Buffalo Grove, IL, USA), using a diamond knife (DiATOME, Hatfield, PA, USA), and thin sections $(50-70 \mathrm{~nm})$ were stained with conventional uranyl acetate/lead citrate. Immunogold labeling with JIM5 (Plant Probes, Leeds, UK) and INRA-RU1 (INRA, Nantes, France) monoclonal antibodies (mAbs) was performed according to previous reports [25].

\section{Live cell immunolabeling}

The incubation steps were performed at RT, in the dark, with constant gentle rotation. Cells were collected by centrifugation at $1000 \times g$ for $1 \mathrm{~min}$, washed $3 \times$ with fresh WHS as described above, and incubated with 1:10 solution of hybridoma supernatant of the primary mAb JIM5 (Plant Probes, Leeds, UK) or INRA-RU1 (INRA, Nantes, France) in WHS for $90 \mathrm{~min}$. The cells were washed $3 \times$ with WHS, and incubated with goat anti-rat IgG conjugated with tetramethylrhodamine (TRITC, Life Technologies $^{\mathrm{TM}}$ Molecular Probes ${ }^{\circledR}$, Eugene, OR, USA) (for JIM5) or anti-mouse IgG conjugated with TRITC (for INRARU1) secondary antibody (1:50 in WHS) for 90 min, after which the cells were washed $3 \times$ with WHS, and kept in the dark until observation.

\section{Nuclei isolation}

All incubations were performed at RT, in a box with ice, and all solutions were kept on ice. The protoplasts were resuspended in $4 \mathrm{~mL}$ of nuclei isolation buffer (NIB) (10 mM MES-KOH pH 5.4; $10 \mathrm{mM} \mathrm{NaCl} ; 10 \mathrm{mM} \mathrm{KCl}$; $2.5 \mathrm{mM}$ EDTA; $250 \mathrm{mM}$ sucrose; $0.1 \mathrm{mM}$ spermine; $0.5 \mathrm{mM}$ spermidine; $1 \mathrm{mM}$ dithiothreitol in deionized water) with $1 \%(\mathrm{v} / \mathrm{v})$ Triton $\mathrm{X}-100$, and incubated in a 
small box with ice, on a shaker with gentle shaking for $40 \mathrm{~min}$. For the sucrose gradient, $3 \mathrm{~mL}$ of $2.5 \mathrm{M}$ sucrose solution were added to a $15 \mathrm{~mL}$ Falcon tube. $3 \mathrm{~mL}$ of a 1.25 $\mathrm{M}$ sucrose solution were gently added onto the previous layer without disturbing it, followed by $3 \mathrm{~mL}$ of a $0.625 \mathrm{M}$ sucrose solution. This procedure was performed for $4 \times 15 \mathrm{~mL}$ Falcon tubes. The nuclei solution was distributed between two of the sucrose gradient tubes, $2 \mathrm{~mL}$ in each tube, without disturbing the sucrose solutions. The tubes were centrifuged at $1000 \times g$ for $10 \mathrm{~min}$. Small aliquots were collected from each resulting layer $(20 \mu \mathrm{L})$ to an Eppendorf tube and $0.5 \mu \mathrm{L}$ of $4^{\prime}, 6$-diamidino2-phenylindole (DAPI, Sigma-Aldrich, St. Louis, MO, USA) solution ( $1 \mathrm{mg} / \mathrm{mL}$ in deionized water) was added. Each layer was observed with the microscope under UV light for nuclei observation and contamination accession.

The top green layer was removed with a pipette and discarded. The layer containing the nuclei fraction was collected into a $15 \mathrm{~mL}$ Falcon tube, and a second incubation with $4 \mathrm{~mL}$ of NIB with detergent was performed using the same conditions described above. The liquid was distributed through the remaining two sucrose gradient tubes and centrifuged at $1000 \times g$ for $10 \mathrm{~min}$. The third layer containing cell debris was discarded. The layer that contained the nuclei was collected with a pipette for DNA isolation or other experiments.

\section{Microscopy}

An Olympus BX60 (Olympus America Inc., Melville, NY, USA) equipped with an Olympus DP73 digital camera, an Olympus IX70 Inverted Microscope equipped with an Olympus DP71 digital camera, an Olympus Fluo View ${ }^{\text {TM }}$ 1200 confocal laser scanning microscope and a ZeissLibra ${ }^{\circledR} 120$ transmission electron microscope (Carl Zeiss SMT Inc., Thornwood, NY, USA) equipped with a Cantega G2 camera (Olympus Soft Imaging Solutions GmbH, Münster Germany) were used for microscopic evaluation of the cells, protoplasts and nuclear fractions.

\section{DNA isolation}

DNA was extracted from fresh nuclei after isolation, and still in NIB with detergent, using a Qiagen DNeasy Plant Kit (Qiagen, USA). For one prep, nuclei isolated from $\sim 10^{5}$ protoplasts $\mathrm{mL}^{-1}$ were mixed with $400 \mu \mathrm{L}$ AP1 with $10 \mu \mathrm{L}$ RNase A. The protocol was then followed according to the manufacturer's instructions with a final elution step in $100 \mu \mathrm{L}$ AE buffer. The DNA samples from the preps were combined and evaluated with a Qubit 3.0 (ThermoFisher Scientific, USA) to verify that there was no residual RNA in the sample, and to assess the DNA concentration. Depending on instrument availability, a NanoDrop $^{\text {TM }} 2000$ spectrophotometer (ThermoFisher Scientific, USA) can also be used to evaluate the DNA.

\section{Results}

\section{Protoplast formation}

The protoplast isolation protocol developed in this study is outlined in Fig. 1. The specific steps of this protocol provide a fast and effective way to obtain $90 \%$ protoplast formation in 2-3 h. It is important to note that neither cellulase alone, nor in combination with other enzymes including RGI-lyase, galactosidase, rhamnosidase, or arabinanases, at $\mathrm{pH} 6$ and $\mathrm{pH}$ 7.2, was enough to break the cell wall and release protoplasts. In fact, the only combination that worked was cellulase together with PL. When cells were incubated in PB for $20 \mathrm{~min}$, plasmolysis was induced, as demonstrated by the separation of the protoplast from the cell wall, especially at the polar zones (Fig. 2a, b). Subsequent enzymatic digestion of the cell wall occurred at the isthmus zone where the protoplast started to emerge (Fig. 2c). Protoplast release took several minutes, culminating after the cell wall at the isthmus ruptured completely (Fig. 2d, e). Once released, each protoplast looked spherical (Fig. 2f), and the final solution contained a mixture of protoplasts, open, empty cell walls, and some cells that did not open (Fig. 2g). Hechtian strands are filaments of cytoplasm that connect the protoplast to the cell wall upon plasmolysis. They demonstrate that focal adhesion zones exist along the cell surface and contribute to signal perception, calcium $\left(\mathrm{Ca}^{2+}\right)$ signaling and focused cell expansion [27]. During the early stages of plasmolysis, Hechtian strands were observable (Fig. 3a). Using TEM, Hechtian strands could be identified in the periplasm, the compartment between the cell wall and the plasma membrane. One end of each strand terminated in the inner cellulosic layer of the cell wall, while the opposite end was attached to the plasma membrane (Fig. 3b-d). Hechtian strands were also observed forming regular arrays (Fig. 3e). TEM analysis of isolated protoplasts revealed the absence of any cell wall component. Each protoplast contained the dense cytoplasm with the chloroplasts engulfing the nucleus (Fig. 3f).

\section{Chelator treatment}

We also verified that the removal of the pectin component alone, accomplished after treating the cells with the chelator EDTA, was not enough to cause the release of the protoplasts (data not shown). The outer layer (OL) of Penium cell wall has a rough, punctate appearance, visible with brightfield microscopy (Fig. 4a). This layer becomes evident after JIM5 immunolabeling, a mAb that recognizes low methyl esterified HG [28], showing the OL forms a HG-rich lattice on the cell surface (Fig. 4b). When the cells were treated with EDTA, a short period of time (20 min) was enough to cause the removal of the OL of the cell wall, visible with brightfield microscopy, as a 
Collect cells from 7-day old culture.

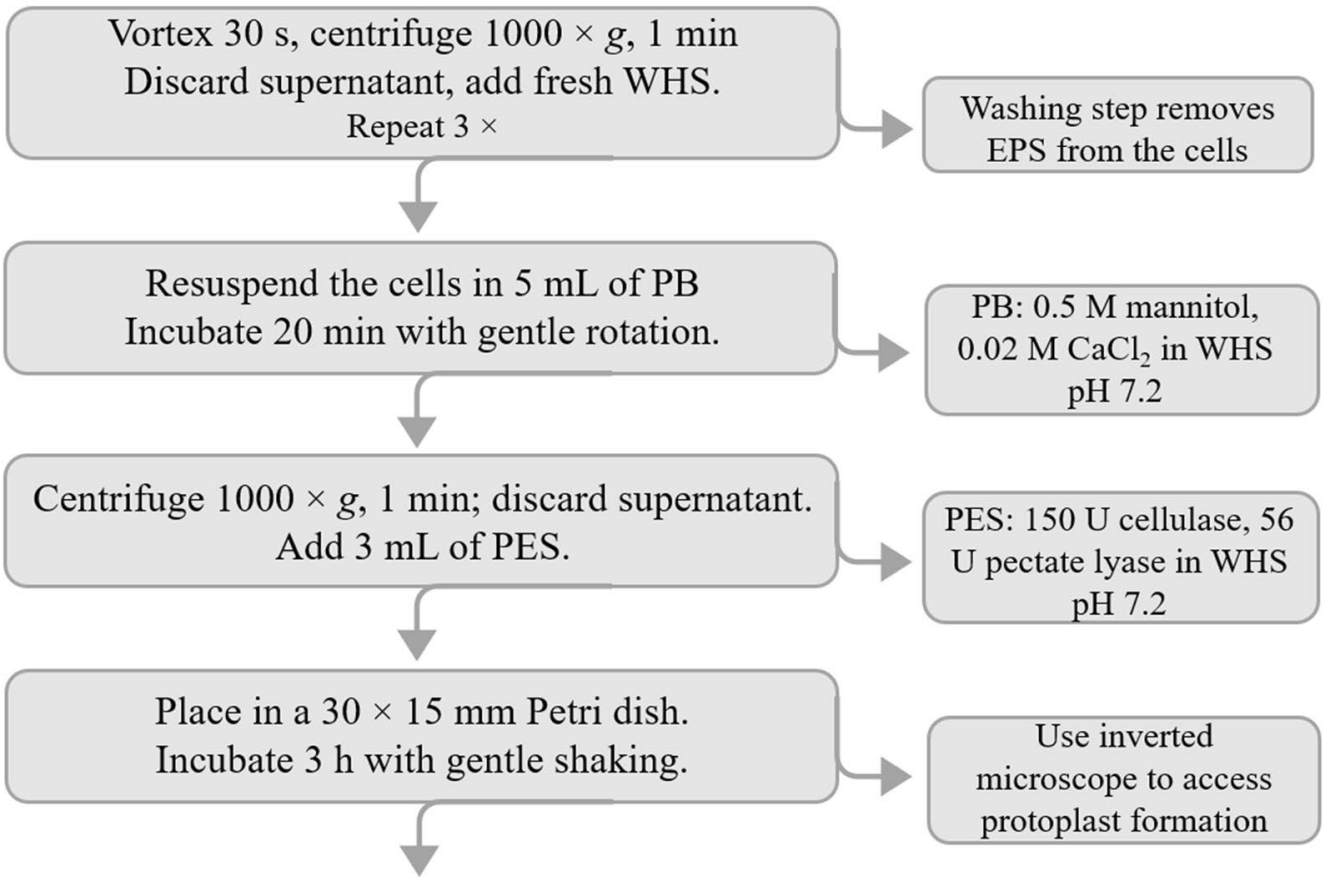

Collect the protoplasts to a $15 \mathrm{~mL}$ tube.

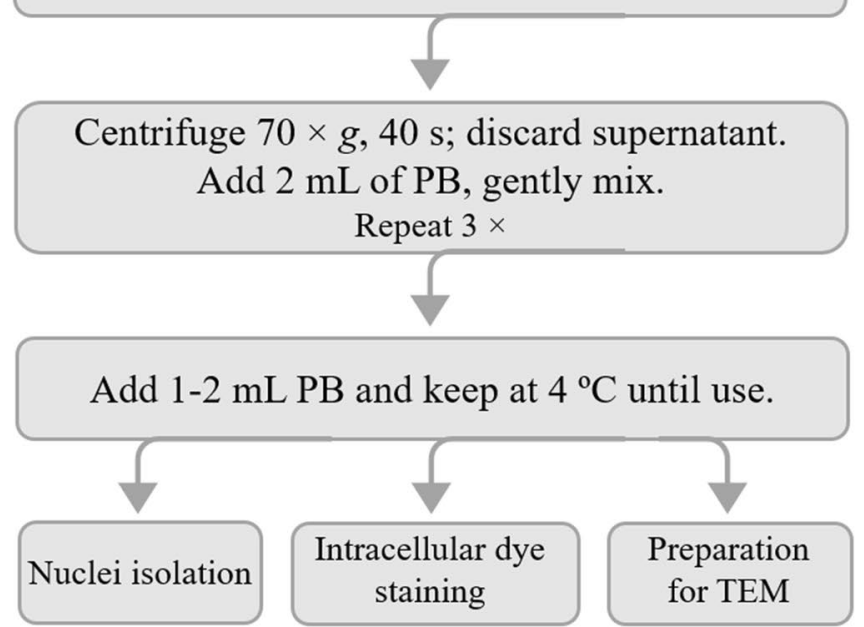

Fig. 1 Graphic outline of the protoplast isolation protocol

smooth appearance of the surface of the cell (Fig. 4c). The absence of fluorescence signal after JIM5 mAb immunolabeling showed that the HG-rich external layer that normally forms the lattice on the cell surface was removed (Fig. 4d). TEM imaging of the untreated cell wall revealed four distinctive layers that constitute Penium cell wall: an external adhesive layer (AL); a pectin domain rich in
$\mathrm{Ca}^{2+}$-complexed $\mathrm{HG}$, the OL that forms a mesh-like lattice; and a middle layer (ML) rich in HG and RGI, that is embedded in the cellulose-rich inner layer (IL) (Fig. 4e). Immunogold labeling with JIM5 showed the presence of the epitopes in the OL and ML (Fig. 4f), while labeling with the RGI backbone-specific mAb, INRA-RU1 [29], showed the distribution of the epitopes in electron 

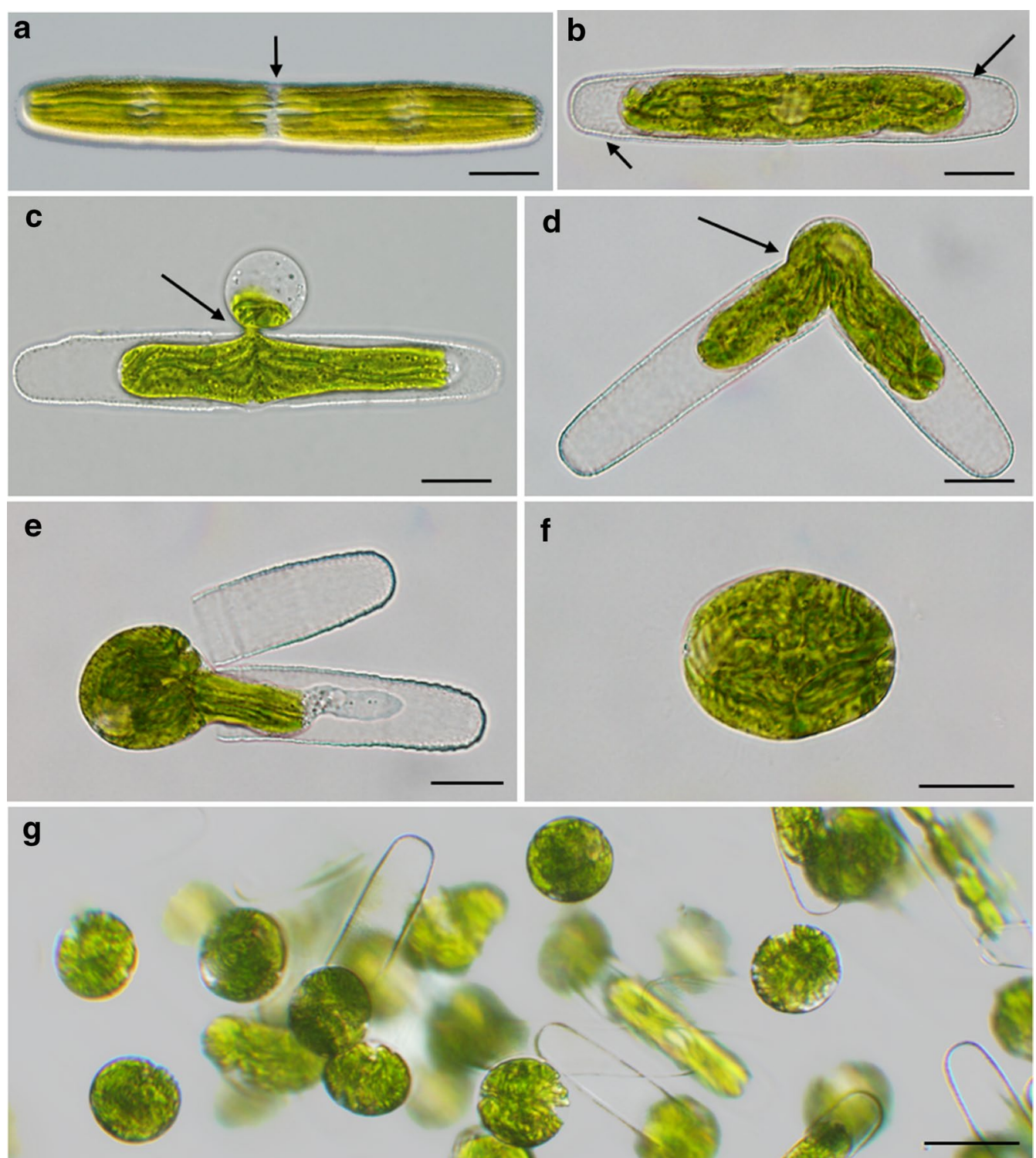

Fig. 2 Differential interference contrast (DIC) images of the stages of protoplast formation. a Typical morphology of a cell. Arrow points to the isthmus zone. b Plasmolysis of the cell after 20 min incubation in protoplast buffer (PB). Note the protoplast separation from the cell wall (arrows). c After $30 \mathrm{~min}$ in protoplast enzyme buffer (PES), a protoplast starts to emerge from a weakened zone in the wall at the isthmus zone (arrow). d The protoplast continues to release from the cell wall, which is now completely open (arrow). e After $2 \mathrm{~h}$, a protoplast is nearly released from the cell wall. f Protoplast. $\mathbf{g}$ Solution with protoplasts and cell wall debris. Scale bars: $\mathbf{a}-\mathbf{e}=15 \mu \mathrm{m} ; \mathbf{f}=25 \mu \mathrm{m} ; \mathbf{g}=50 \mu \mathrm{m}$

dense zones in the ML (Fig. 4g). When cells were treated with EDTA, the HG-rich OL was completely removed, while the other layers AL, ML and IL remain unaltered (Fig. 4h). JIM5 immunogold labeling resulted in the absence of labeling in the area where the OL should be, and a reduction of JIM5 gold particles in the ML (Fig. 4i). EDTA treatment did not affect INRA-RU1 labeling of the RGI, located in the ML (Fig. 4j).

When cells were allowed to recover after EDTA treatment, they started to produce the HG-rich lattice in the isthmus zone after 4 days, as revealed by JIM $5 \mathrm{mAb}$ immunolabeling (Fig. 5a). TEM imaging showed a new HG-rich OL deposited in the isthmus zone and being translocated toward the poles upon cell expansion. The polar zone still maintained the lattice-free loci (Fig. 5b). Cells allowed to recover for 1 day displayed an unaltered ML, as shown after INRA-RU1 mAb immunolabeling (Fig. 5c), and the initiation of the deposition of new HG in the isthmus zone, as shown after JIM5 mAb immunogold labeling (Fig. 5d). Full recovery was observed after 

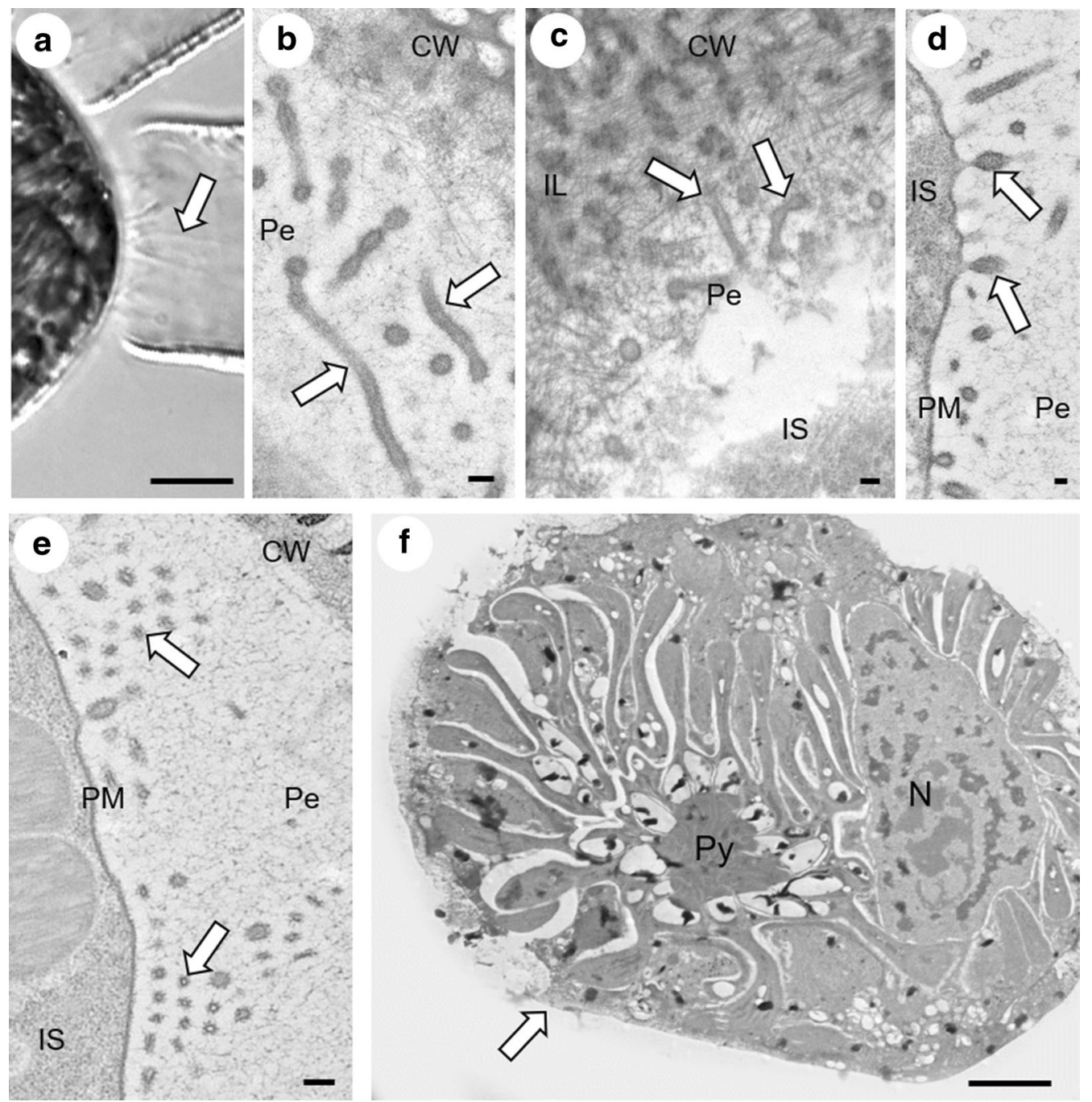

Fig. 3 Differential interference contrast (DIC) (a) and transmission electron microscopy (TEM) images (b-f) showing the ultrastructure of protoplast formation. a During the first minutes of incubation in PB, the protoplast plasmolyzes and separates from the cell wall; however, numerous fine strands (arrow), i.e., Hechtian strands become apparent. $\mathbf{b}$ Hechtian strands bind the plasma membrane to the cell wall (arrows). c One end of the strands is connected to the inner layer of the cell wall (arrows). d The other end of the strands emerge from the plasma membrane (arrows). e Cross section through the plasmolyzed cell reveals that the strands are organized in arrays (arrows). f Protoplast. Note the nucleus (N), the pyrenoid of the chloroplast (Py) and the absence of a cell wall (arrow). CW, cell wall IL, cellulose-rich inner layer IS, intracellular space Pe, periplasm PM, plasma membrane. Scale bars: $\mathbf{a}=2 \mu \mathrm{m} ; \mathbf{b}-\mathbf{e}=100 \mathrm{~nm} ; \mathbf{f}=500 \mathrm{~nm}$

4 days, after which the typical distribution of JIM5 and INRA-RU1 gold particles was visible in both the ML and the OL (Fig. 5e, f).

\section{Intracellular dyes}

In this study, we labeled both protoplasts and walled cells with several intracellular dyes and imaged labeling patterns with confocal laser scanning microscopy (CLSM). The nuclear stain, DAPI, labeled the nucleus positioned in the isthmus of walled cells, while in protoplasts the nucleus was found at different loci, depending on the positioning of the displaced chloroplasts (Fig. 6a). The ratiometric excitation $\mathrm{pH}$ indicator BCECF AM, highlighted the elongate inter-plastid lobe spaces in both cells and protoplasts (Fig. 6b), and did not accumulate in any organelle. 5(6)-CFDA, a stain used to identify cytoplasm and cell viability, showed a more generalized fluorescence throughout the intracellular space in both cells and protoplasts (Fig. 6c). DiOC6(3), a probe for the endoplasmic reticulum (ER), labeled the reticulated network of long ER tube-like structures in walled cells, while in protoplasts the ER network formed flattened and 

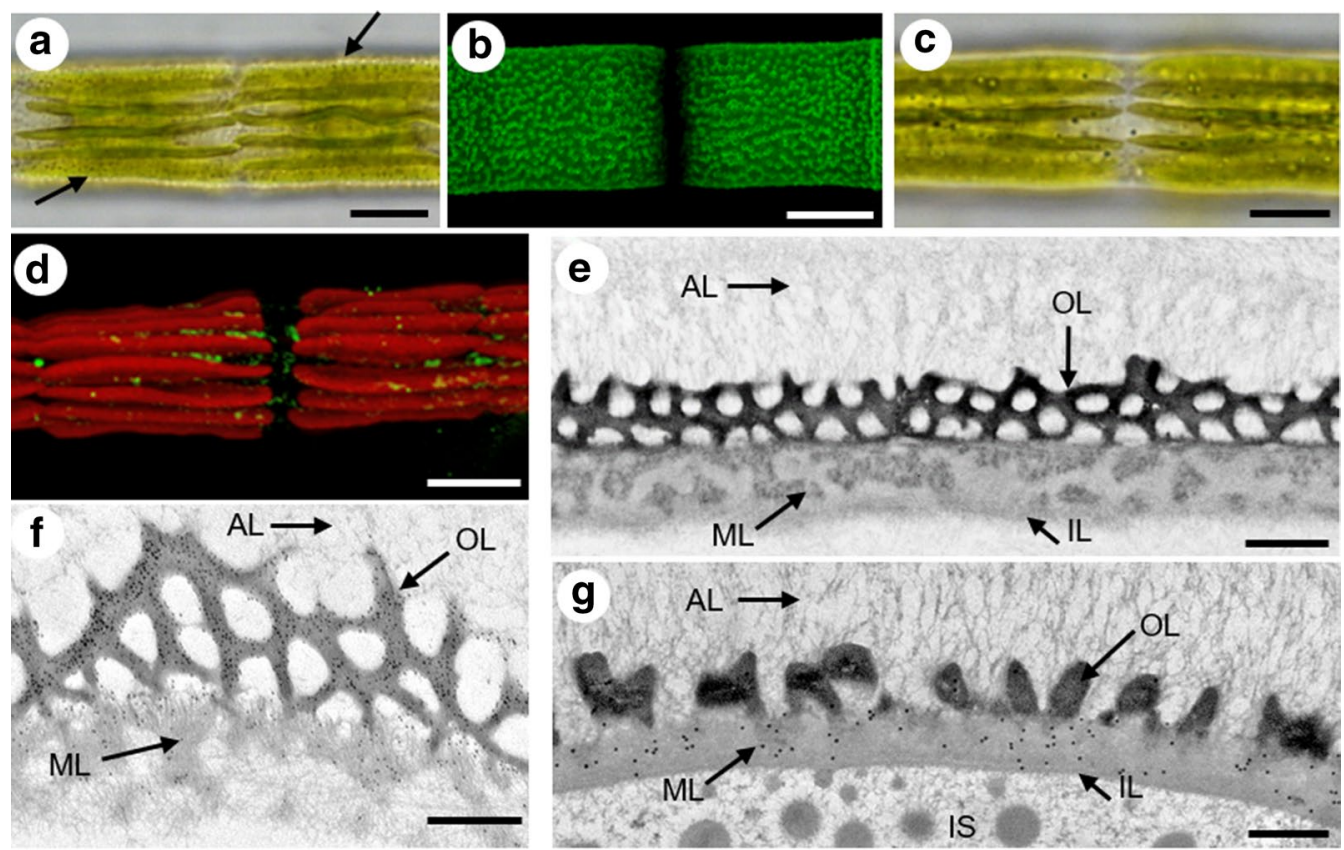

h
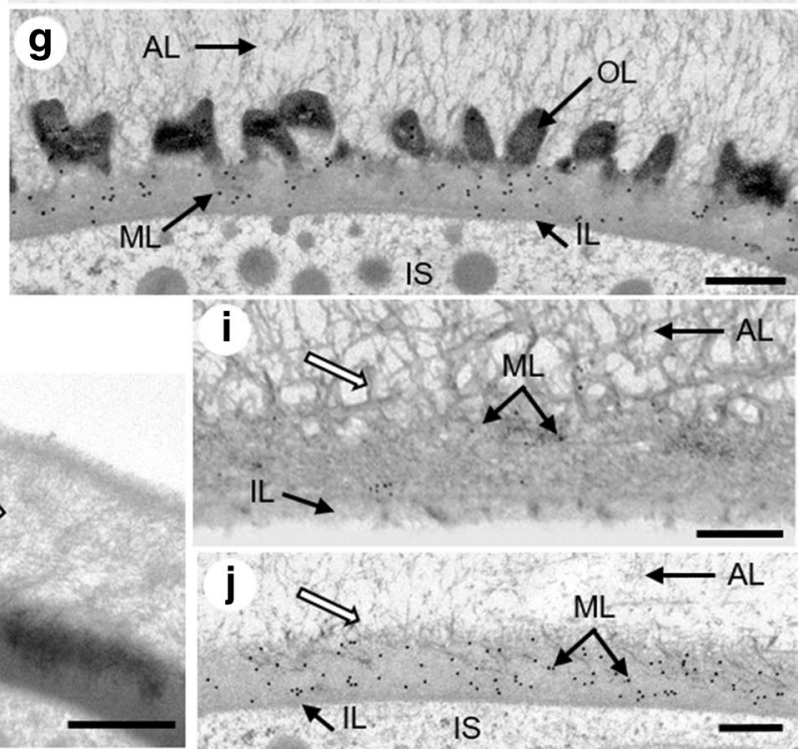

Fig. 4 Differential interference contrast (DIC) (a, $\mathbf{c})$, immunofluorescence (b, d) and transmission electron microscopy (TEM) (e-j) images of a Penium cell wall before and after treatment with $20 \mathrm{mM}$ EDTA for $20 \mathrm{~min}$. a General appearance of a cell, where the outer layer (OL) of the cell wall has a rough, punctate appearance (arrows). b JIM5 mAb immunolabeling of a regular cell shows the homogalacturonan (HG)-rich OL that forms a lattice with a punctate shape. $\mathbf{c}$ After treatment with EDTA, the surface of the cell appears smooth, devoid of the OL. d JIM5 mAb immunolabeling of a treated cell shows the absence of labeling of the cell wall. The red color is the autofluorescence signal emitted by the chloroplast. e Ultrastructure of the cell wall of an untreated cell showing the external adhesive layer (AL), the HG-rich OL that forms the lattice, and the rhamnogalacturonan I (RGI)-rich middle layer (ML) that is embedded in a cellulose-rich inner layer (IL) (arrows). f JIM5 mAb immunogold labeling of the cell wall of an untreated cell shows the gold particles distribute to both OL and ML (arrows). $\mathbf{g}$ INRA-RU1 mAb immunogold labeling of the cell wall of an untreated cell shows the gold particles located in the ML (arrow). h TEM of a treated cell shows the OL completely removed (white arrow), while AL, ML and IL remain intact (black arrows). i JIM5 mAb immunogold labeling of a treated cell shows the lack of the OL (white arrow), and consequently no labeling, and the presence of gold particles in ML (black arrows). $\mathbf{j}$ INRA-RU1 mAb immunogold labeling of a treated cell shows the lack of the OL (white arrow) and the labeling of the ML (black arrows). IS, intracellular space. Scale bars: $\mathbf{a}-\mathbf{d}=10 \mu \mathrm{m} ; \mathbf{e}, \mathbf{g}, \mathbf{h}, \mathbf{j}=500 \mathrm{~nm} ; \mathbf{f}=350 \mathrm{~nm} ; \mathbf{i}=450 \mathrm{~nm}$

irregular short tubes (Fig. 6d). Lyso Tracker ${ }^{\mathrm{TM}}$ Red labeled the numerous acidic organelles in both walled cells and protoplasts (Fig. 6e), while Yeast Vacuole Membrane marker, MDY-64, a probe for vacuoles, stained a network of small vacuoles distributed throughout the intracellular space, along the lobes of the chloroplast (Fig. 6f). The lipid marker BODIPY ${ }^{\mathrm{TM}} \mathrm{FL} \mathrm{C}_{11}$-Phosphocholine analogue probe showed a pattern of strongly fluorescent spherical domains in the plasma membrane (Fig. 7a), while the
BODIPY $^{\mathrm{TM}}$ FL C5-Ceramide lipid analogue probe labeled some organelle membrane structures distinct from those observed for ER- and vacuole-probes in cells, and in protoplasts it was possible to observe those structures with the shape of thin, curved entities (Fig. 7b). The lipid domain probe Di-4-ANEPPDHQ revealed the staining of numerous lipid domains in the plasma membrane (Fig. 7c). FM ${ }^{\mathrm{TM}} 1-43$, a label used to monitor membrane uptake during endocytosis, revealed a time-dependent 

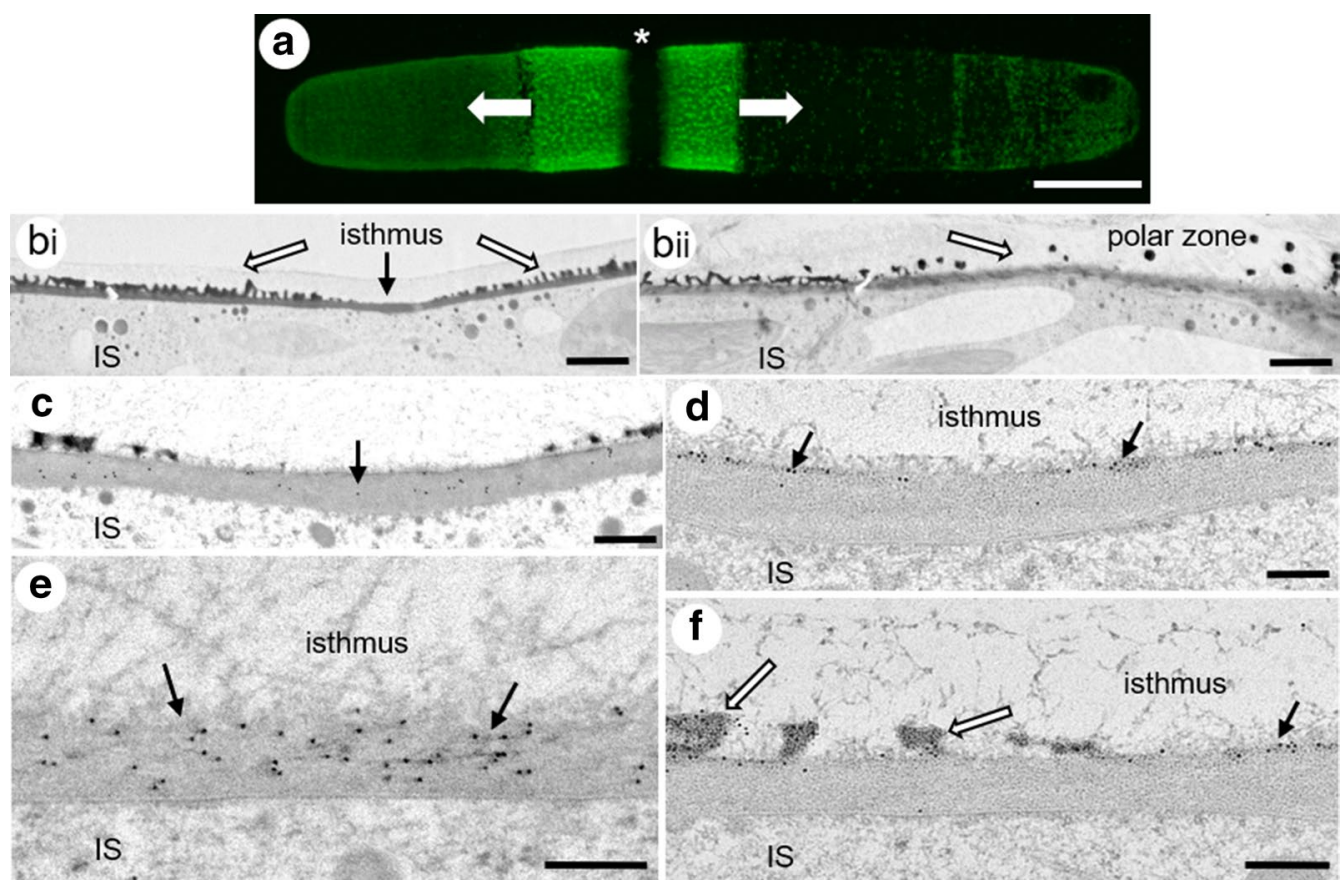

Fig. 5 Immunofluorescence (a) and transmission electron microscopy (TEM) (b-f) images of a Penium cell wall after treatment with 20 mM EDTA for 20 min and subsequent recovery. a JIM5 mAb immunolabeling of a cell recovered for 4 days. Note that homogalactan (HG) is produced at the isthmus $(*)$ and is translocated outward toward the poles (arrows). b TEM of the cell wall of a recovering cell. New HG is produced at the isthmus zone (i) and is translocated outward toward the poles (white arrows). The polar zone contains the oldest wall of the cell (ii), and has no HG, which was removed by the treatment (white arrow). c INRA-RU1 mAb immunogold labeling of the isthmus zone of a cell recovered for 1 day shows the presence of gold particles at the isthmus (arrows). d JIM5 mAb immunogold labeling of the isthmus zone of a cell recovered for 1 day shows the start of a new cell wall being secreted, shown by the presence of few gold particles in the isthmus zone (arrows). e INRA-RU1 mAb immunogold labeling of the isthmus zone of a cell recovered for 4 days shows a dense labeling of the wall at the isthmus (arrows). f JIM5 mAb immunogold labeling of the isthmus zone of a cell recovered for 4 days shows the labeling of the wall at the isthmus (black arrow) and in the developing $\mathrm{HG}$ lattice (white arrows). IS, intracellular space. Scale bars: $\mathbf{a}=15 \mu \mathrm{m} ; \mathbf{b}=2 \mu \mathrm{m} ; \mathbf{c}, \mathbf{d}=400 \mathrm{~nm} ; \mathbf{e}, \mathbf{f}=500 \mathrm{~nm}$

labeling pattern. Labeling of the plasma membrane was observed after $5 \mathrm{~min}$ in walled cells (Fig. $7 \mathrm{~d}, 5 \mathrm{~min}$ ), and after $1 \mathrm{~min}$ in protoplasts (Fig. 7e, $1 \mathrm{~min}$ ). After 10-15 min, some areas of the plasma membrane facing the intracellular compartment showed some fluorescent thickenings (Fig. 7d, $10 \mathrm{~min}$ ), while in protoplasts, spherical membrane structures stained the periphery of the plasma membrane (Fig. 7e, $15 \mathrm{~min}$ ). With increasing time (20-30 min), fluorescent bodies, most likely vacuoles, were observed in the cytoplasm (Fig. 7e, $30 \mathrm{~min}$ ), and after longer periods of time ( $1-2 \mathrm{~h}$ ), numerous vacuole-like components were labeled in both walled cells (Fig. 7d, $60 \mathrm{~min}$ ) and protoplasts (Fig. 7e, $120 \mathrm{~min}$ ). It is significant to note that in order to document the incorporation of $\mathrm{FM}^{\mathrm{TM}} 1-43$ in the plasma membrane within the first minutes of incubation, single pictures were taken (Fig. 7d, $5 \mathrm{~min}, 10 \mathrm{~min}$, Fig. 7e, $1 \mathrm{~min}, 15 \mathrm{~min}, 30 \mathrm{~min}$ ), while for all the other dyes, and for the latest imaging of $\mathrm{FM}^{\mathrm{TM}} 1-43$ (Fig. 7d, 60 min, Fig. 7e, 120 min), z stacks were taken in order to obtain 3-dimensional pictures.

\section{Nuclei isolation}

Intact nuclei from isolated protoplasts were obtained after two sequential sucrose gradient centrifugation steps. Initial treatment with the detergent-based medium, NIB, yielded a green solution that contained a mixture of nuclei, chloroplasts and cell debris (Fig. 8a, b). After the first centrifugation, two green layers or fractions were obtained. The top fraction did not contain any nuclei, as assessed after staining with DAPI (Fig. 8c). The green middle fraction, between the 0.625 and $1.25 \mathrm{M}$ sucrose layers (Fig. 8d), contained the nuclei, accessed after DAPI staining, and also other cellular components (Fig. 8e). A second NIB extraction and gradient centrifugation step was then employed in order to increase the yield of the isolated nuclei. After this second centrifugation, three fractions were observed: a top green layer containing the remaining chlorophyll, a white fraction in the interface between the 0.625 and $1.25 \mathrm{M}$ sucrose layers that contained the pure nuclei (Fig. 8f), and a fine green fraction in the interface between the 1.25 and $2.5 \mathrm{M}$ sucrose 

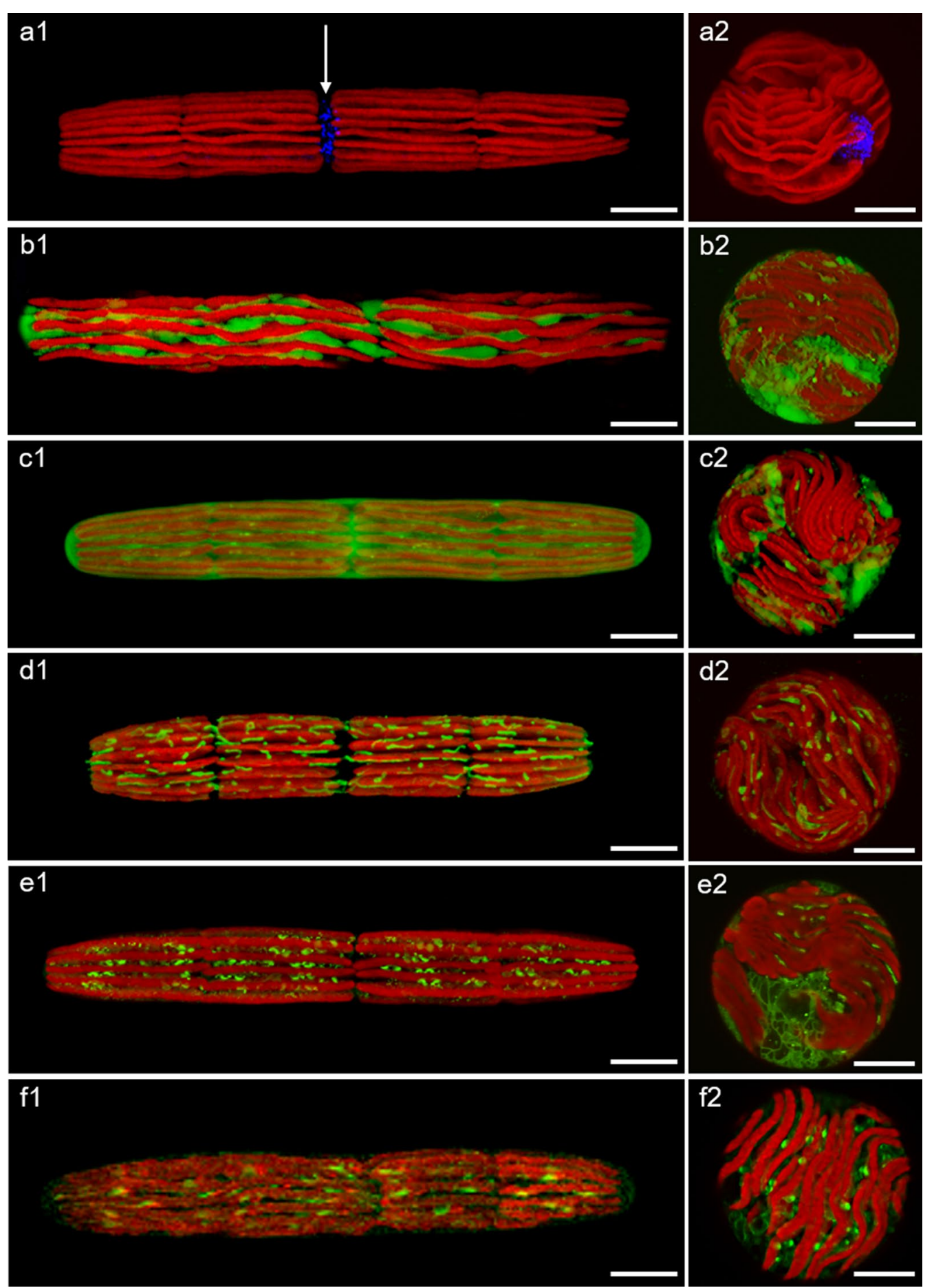

Fig. 6 Confocal laser scanning microscopy (CLSM) images of Penium cells (a-f1) and protoplasts (a-f2) stained with intracellular dyes (green), merged with the autofluorescence signal emitted by the chloroplast (red). a DAPI staining of the nucleus, localized in the isthmus zone (1, arrow) and in a protoplast (2). b BCECF AM staining of the cytoplasm. c 5(6)-CFDA staining of the cytoplasm. d DiOC6(3) staining of the endoplasmic reticulum (ER). e Lyso Tracker ${ }^{\mathrm{TM}}$ Red staining of lysosomes and autophagic vacuoles. f Yeast Vacuole Membrane marker, MDY-64, staining of vacuole membranes. Scale bars: $15 \mu \mathrm{m}$ 

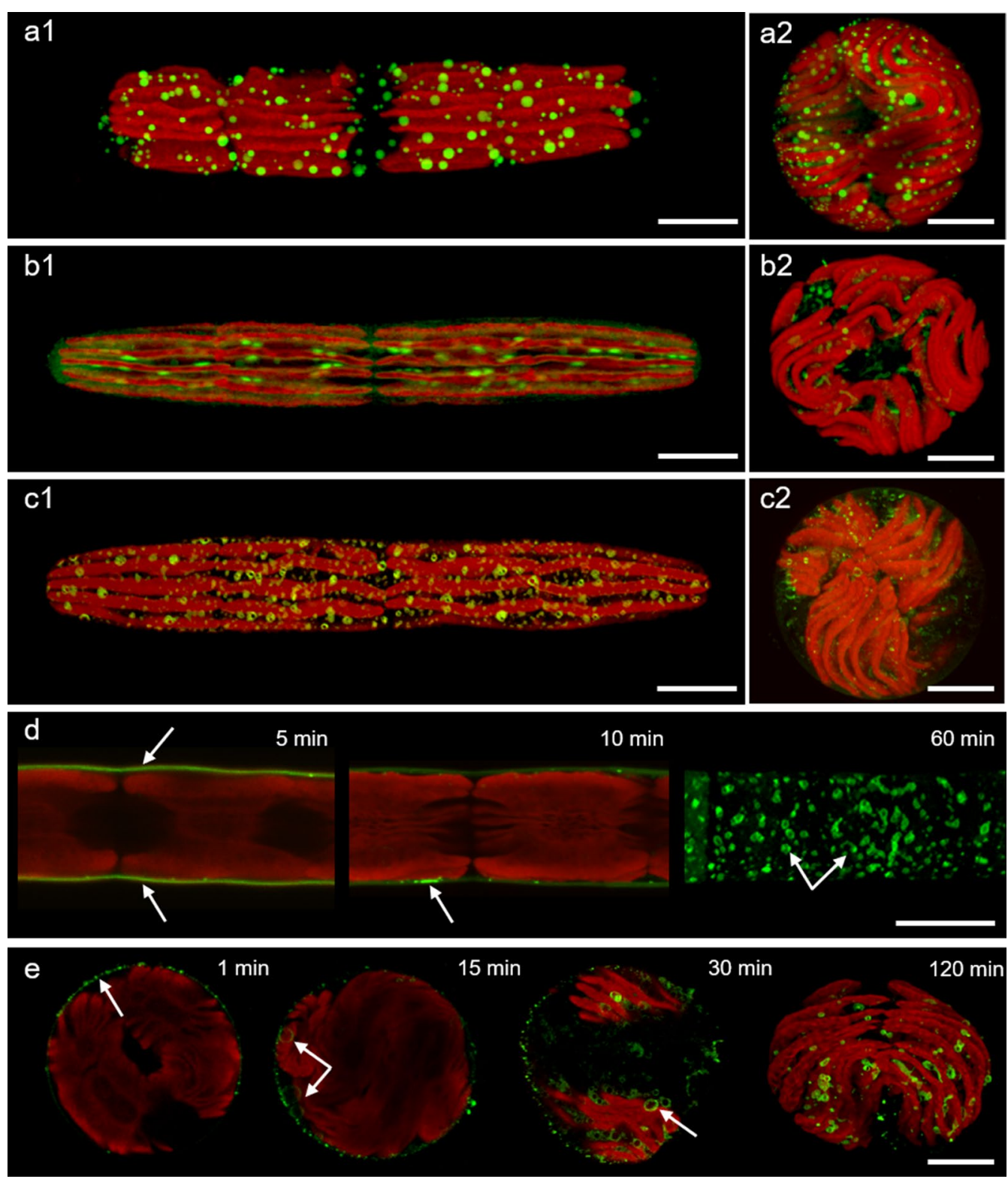

Fig. 7 Confocal laser scanning microscopy (CLSM) images of Penium cells $(\mathbf{a} 1, \mathbf{b} 1, \mathbf{c} 1, \mathbf{d})$ and protoplasts $(\mathbf{a} 2, \mathbf{b} 2, \mathbf{c} 2, \mathbf{e})$ stained with membrane mapping intracellular dyes (green), merged with the autofluorescence signal emitted by the chloroplast (red). a BODIPY ${ }^{\mathrm{TM}} \mathrm{FL} \mathrm{C}_{11}-\mathrm{Phosphocholine}$ staining. $\mathbf{b}$ BODIPY ${ }^{\mathrm{TM}} \mathrm{FL}$ C5-Ceramide staining. $\mathbf{c}$ Di-4-ANEPPDHQ staining of domains in the plasmam membrane. $\mathbf{d}_{\mathrm{FM}}^{\mathrm{TM}} 1-43$ stains the plasma membrane after 5 min of incubation (arrows); fluorescent thickening in some areas of the plasma membrane appear after 10 min (arrow), and after $60 \mathrm{~min}$, the dye is observed in cytoplasmic compartments (arrows). e Similarly to walled cells, FM ${ }^{\mathrm{TM}} 1-43$ labels the plasma membrane of protoplasts after 1 min incubation (arrow); after 15 min spherical structures in the periphery of the plasma membrane are observable (arrows), and after 30 min the dye locates in cytoplasmic compartments (arrow), being completely incorporated after $120 \mathrm{~min}$. Note that (d) $1 \mathrm{~min},(\mathbf{e}) 1,15$ and $30 \mathrm{~min}$ are single shot pictures, while the remaining pictures are z stacks. Scale bars: $15 \mu \mathrm{m}$

layers (Fig. 8g), that contained cell wall debris and whole cells that did not yield protoplasts (Fig. 8h).

\section{DNA isolation from isolated nuclei}

One of the goals for isolating the nuclei was to obtain a DNA fraction with a high degree of purity. Using the protocol described above, we isolated DNA from the nuclear fraction and confirmed its quality by spectrophometric and electrophoretic analyses. The final DNA concentration was determined to be $2.55 \mu \mathrm{g}$ from the initial starting material of $\sim 10^{6}$ nuclei. The genomic DNA samples were of sufficient quality to generate genomic DNA 

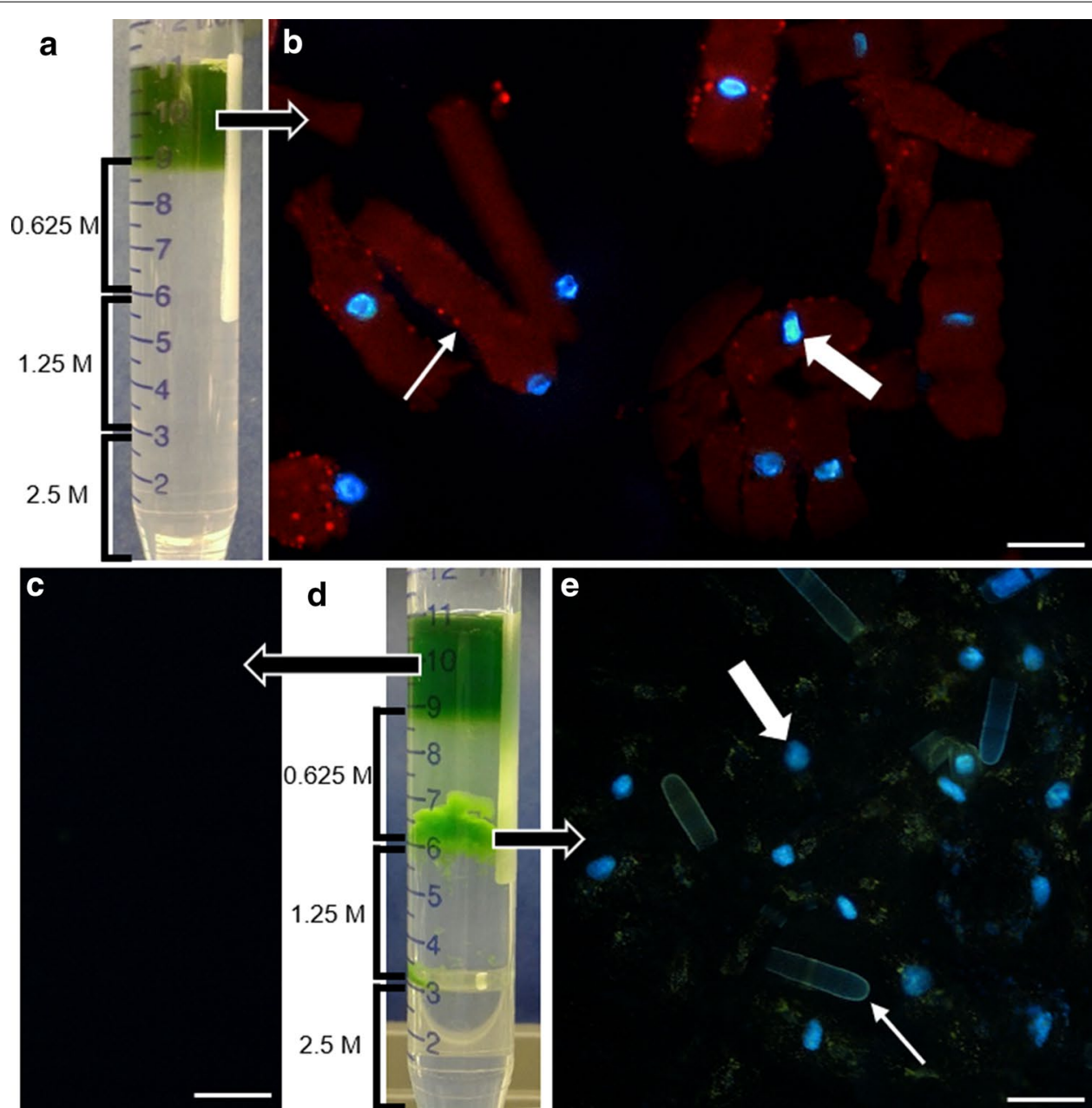

d

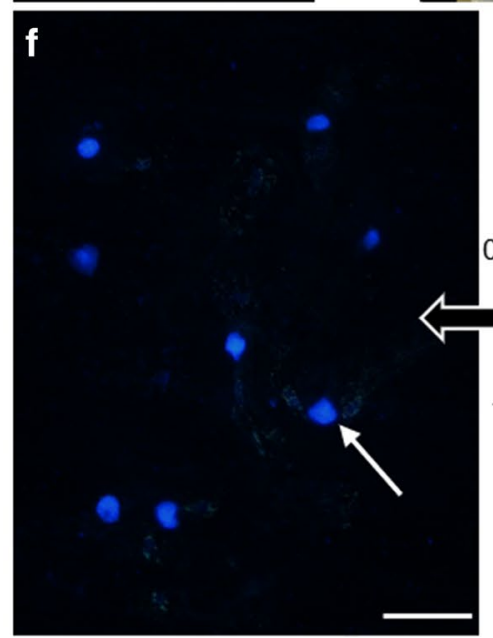

g
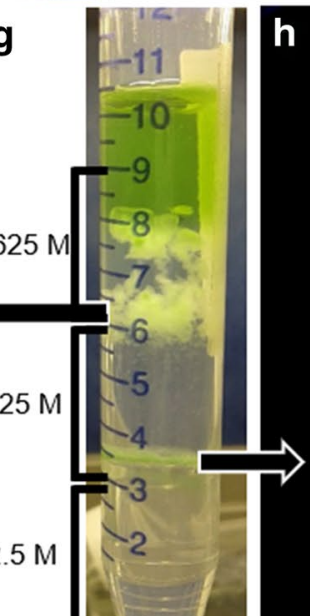

Fig. 8 Nuclei isolation from protoplasts. a After the protoplast isolation and incubation in nuclei isolation buffer (NIB), the crude mixture of nuclei and cell debris (green solution) is placed on a sucrose gradient. b DAPI staining of the crude solution shows the nuclei (large arrow) attached to the chloroplasts (small arrow). c After the first centrifugation, a top green liquid layer is visible and does not contain any nuclei as determined after staining with DAPI. d A green fraction, between the 0.625 and the $1.25 \mathrm{M}$ sucrose layers is visible, and after DAPI staining shows the presence of the nucle (large arrow), although cell debris are also present (small arrow) (e). f After the second centrifugation in sucrose gradient, the interface between the 0.625 and $1.25 \mathrm{M}$ sucrose layers contains the pure nuclei fraction (arrow), visible after DAPI staining. $\mathbf{g}$ Three layers were observed: a top green layer containing chlorophyll, a white middle layer containing the nuclei, and a third layer in the interface between the 1.25 and $2.5 \mathrm{M}$ sucrose containing cell wall debris and cells that did not release protoplasts $(\mathbf{h})$. Scale bars: $50 \mu \mathrm{m}$ 
libraries for successful MiSeq and HiSeq (Illumina, USA) sequencing (data not shown).

\section{Discussion}

In this work we present a simple and effective protocol for generating protoplasts from the charophyte, Penium. This alga is a unique model organism in that it is unicellular, easy to culture and maintain in the laboratory, responds to external treatments, and its mechanism for depositing cell wall components during expansion and development may be monitored using various microscopy technologies. Furthermore, the subcellular machinery for the production of these wall components is elaborate and provides an effective system for the analysis of the roles of endomembrane trafficking, secretion and plasma membrane dynamics in plant cells $[7,11,17]$. Here, we present a toolbox of intracellular markers that can be used in vivo in protoplasts to study the location and organization of subcellular components and membrane domains. Likewise, we provide the methodology for the isolation of nuclei and the subsequent extraction of nuclear DNA for downstream applications, including sequencing.

\section{Cell walls without the HG lattice are not compromised to yield protoplasts}

The outer layer of the Penium cell wall is distinguished by an interconnected network of electron dense "struts" (i.e., the lattice) that are composed of HG complexed with $\mathrm{Ca}^{2+}$ [11]. This pectic domain can be solubilized through short incubation periods in a chelator, e.g., EDTA (Fig. 4). EDTA effectively removes the outer lattice from the cell wall but does not remove the HG located in the ML. This is most likely due to the fact that EDTA does not affect $\mathrm{HG}$ unless it is complexed with $\mathrm{Ca}^{2+}$ as it is in the OL. Additionally, it may not be able to effectively penetrate into, and act in, the denser inner wall layers. It is also possible that the HG in the ML may be protected from dissolution by its association with RG-I. After testing several enzymes, we determined that only a mixture of cellulase and PL yielded protoplasts. PL catalyzes HG by $\beta$-elimination of $(1 \rightarrow 4)$ - $\alpha$-D-galacturonan [30], and it has been reported to remove the HG-rich OL that forms the outer lattice in Penium $[15,18]$. Our results show that only PL, acting at the OL level of the cell wall, combined with cellulase, acting at the IL level, were sufficient to compromised wall integrity at the isthmus in order to release the protoplast.

\section{Organelle and cytosol markers}

Subcellular labels or markers that can be applied to live cells and monitored over time have been valuable tools to elucidate plant cell dynamics. Transformation of Penium has not been reported to date, therefore the ability of the protoplasts to take up such specific dyes is an important tool. This enables comparative analysis of their location and organization within the cell, as well as their changes over time.

BCECF AM is an acetoxylmethyl nonfluorescent compound that after diffusing into the cell is hydrolyzed by nonselective intracellular esterases, resulting in a fluorescent dye [31]. BCECF AM is frequently used as a ratiometric excitation $\mathrm{pH}$ indicator, since its absorption profile changes significantly with the intracellular $\mathrm{pH}[32$, 33]. It's dual excitation characteristics allows researchers to compare fluorescence intensity ratios measured at two different excitation wavelengths, and correlate to $\mathrm{pH}$ after comparison with calibration methods [31]. It has been used in animal cell physiological studies to measure intracellular $\mathrm{pH}$ dynamics [34]; as a marker for vacuolar $\mathrm{pH}$ in protoplasts from several species, including alfalfa (Medicago sativa) [35], barley (Hordeum vulgare) [36, 37], and quince (Cydonia oblonga) [38]; for protein storage vacuoles in sunflower (Helianthus annuus), cotton (Gossypium hirsutum) and peanut (Arachis hypogaea) $[39,40]$; and as a marker for vacuolar membrane disintegration in tobacco (Nicotiana benthamiana) protoplasts [41]. It was also employed in cells of the charophyte, Chara australis, although in this case, the dye did not prove useful as a cytosolic $\mathrm{pH}$ indicator, as it accumulated in the mitochondria, although it could be used for probing mitochondrial $\mathrm{pH}$ changes [42]. In Penium, the BCECF AM labeling pattern observed was characterized by elongated patches of fluorescence along the cytoplasmic lobes, more distinct in walled cells than in protoplasts due to the contortions of the chloroplast. Also, it did not accumulate in any intracellular compartment (Fig. 6b), which is important if considering future studies with the intention to use this probe to follow cytosolic $\mathrm{pH}$ dynamics.

5(6)-CFDA is a cell-permeant esterase substrate, used as a viability probe, through the fluorescence released upon hydrolysis by intracellular esterases and also by testing cell-membrane integrity, required for intracellular retention of the fluorescent product. It is widely used in cell biology studies, including bacteria [43], cancer cells $[44,45]$, to plants $[46,47]$. This dye also worked very well with both Penium walled cells and protoplasts where a generalized fluorescent masking throughout the cytoplasm was observed when cells were alive (Fig. 6c).

DiOC6(3) is a versatile lipophilic cationic fluorochrome [48] that is primarily used to stain both animal and plant cell ER [49-51] and Golgi apparatus [52], although it can also stain mitochondria [53]. In this study, we show that this label effectively marks the ER in Penium cells, where the interconnected network of tube-like cisternae was 
observed. In addition, the changes therein, when walled cells yielded protoplasts were visible, where the ER network showed an irregular and flattened appearance, perhaps due to the spherical shape of the protoplast that compresses the endomembrane system (Fig. 6d).

Lyso Tracker ${ }^{\mathrm{TM}}$ dyes are fluorescent acidotropic probes used for labeling and tracing acidic organelles in live cells, such as lysosomes and some vacuoles. This probe has been used as a tool in many plant-based studies, where protoplasts have a crucial role in localization studies involving processes such as proteolytic activity upon leaf senescence [54-56] or upon cell death [57]. This dye labeled numerous subcellular acidic components in both Penium cells and protoplasts (Fig. 6e).

The Yeast Vacuole Membrane marker, MDY-64, is a hydrophobic styryl dye that has been used to label the membrane of yeast vacuoles [58], as well as the complex vacuolar organization in plants [59-61]. In both walled cells and protoplasts, MDY-64 labeled a network of small vacuoles in the cytoplasm, located at intervals between the chloroplast lobes (Fig. 6f).

\section{Membrane lipid markers}

Recently, there has been a considerable increase in research examining specific domains in the plasma membrane. Though controversial at first, the presence of such domains, sometimes referred to as 'lipid rafts' in plants, has now been more widely accepted [62,63]. Several specific labels can be used for identifying these plasma membrane structures. The BODIPY fluorophore (boron dipyrromethene 4,4-difluoro-5,7-dimethyl-4-bora-3 $\alpha, 4 \alpha$ diaza-s-indacene) was originally used to study secretory pathways in mammalian cells [64]. BODIPY-labeled sphingolipid analogues have been reported as valuable tools to study membrane microdomains, as lipid rafts are enriched in sphingolipids [65-67]. The BODIPY ${ }^{\mathrm{TM}}$ FL $\mathrm{C}_{11}$-Phosphocholine lipid analogue is composed of a sphingosine linked to a fatty acid, and to a BODIPY fluorophore. It has been used to observe lipid phases in plant protoplasts [68], and has shown to be an effective marker for endocytosis dynamics in tobacco pollen tubes [69]. In Chara corallina, this label marked the ER and lipid droplets [70]; however, in Penium, it labeled well defined lipid domains of the plasma membrane with a similar spherical appearance in both walled cells and protoplasts (Fig. 7a). The BODIPY ${ }^{\mathrm{TM}}$ FL C5-Ceramide lipid analogue has been used to follow lipid internalization and membrane dynamics in animal research [71-73], and has been reported to be a probe for the Golgi apparatus [74]. In Penium, this probe labeled subcellular membranes of structures that appeared different from any of the other dyes used, and were located in the inter-plastid spaces of the protoplasts (Fig. $7 \mathrm{~b}$ ). We propose that these organelles may be Golgi bodies, although further work is needed to confirm this idea.

Di-4-ANEPPDHQ is a polarity sensitive styryl dye that allows the study of the physico-chemical properties of the cell membrane, which changes depending on the lipid packing [75], and has emerged as an excellent probe for lipid membrane domains, as it can be used to differentiate between liquid-ordered and -disordered lipid phases $[76,77]$. It has recently been presented as a valuable tool to the study lipid rafts [67]. First proposed by Simons and Ikonen [78], rafts, which derive from the dynamic association of sphingolipids and cholesterol, move within the fluid lipidic bilayer, and are thought to have a vital role in membrane trafficking. In Penium, di-4-ANEPPDHQ showed a distinct labeling pattern within the plasma membrane (Fig. 7c), confirming the presence of microdomains, possibly lipid rafts.

The membrane-selective $\mathrm{FM}^{\mathrm{TM}}$ dyes, $\mathrm{FM}^{\mathrm{TM}} 1-43$ and $\mathrm{FM}^{\mathrm{TM}}$ 4-64 [79, 80], are water soluble, nontoxic, amphiphilic styryl fluorochromes that insert into the outer bilayer of the plasma membrane and are not metabolized by the cell. They have become useful probes to visualize and follow vesicle trafficking in endocytosis and exocytosis events in living cells [80-82], particularly relevant in medical research [83, 84]. In plant cells, $\mathrm{FM}^{\mathrm{TM}} 4-64$ [68, 85-87], and $\mathrm{FM}^{\mathrm{TM}} 1-43$ [88-90] have been extensively used as probes for imaging lipid dynamics, secretory vesicle trafficking and endocytosis and exocytosis events. Studies performed on the CGA C. corallina report their relevance as endocytic markers to monitor membrane internalization $[91,92]$. In both walled cells and protoplasts of Penium, uptake of the $\mathrm{FM}^{\mathrm{TM}}$ dyes was time dependent. At first the probe localizes in the plasma membrane, and over time it is internalized within vesicle membranes and accumulates inside the cell (Fig. 7d, e), suggesting a similar process to that seen in land plants and highlighting the potential for using these dyes in future studies of the endomembrane system.

\section{Nuclei isolation}

Protoplast isolation is a useful preparatory technology for the isolation of organelles and macromolecules therein. For example, this method has been used for the isolation of nuclei-rich fractions [93-95]. Obtaining highly pure DNA of superior quality, i.e., no RNA or chloroplast DNA is essential for certain downstream analysis methods. In this study, we used nuclei isolated from protoplasts prior to DNA isolation, which provided a source of genomic DNA of sufficient quality for subsequent sequencing analysis. Here, we present a reliable protocol for gentle disruption of protoplasts, followed by a simple gradient centrifugation that yields large amounts of undamaged nuclei that are free from cellular debris and 
plastid DNA. This method requires minimal equipment and approximately $2 \mathrm{~h}$ of handling time. DNA from the nuclei fraction can then be obtained using commercial DNA isolation kits.

\section{Future applications of protoplasts in Penium studies}

The isolation and culturing of protoplasts from Penium offer new and innovative possibilities in cell and molecular biology studies. First, examination of the regeneration of a new cell wall, accompanied by the morphogenetic events that ultimately yield the cylindrical shape, will provide important insight into the fundamentals of plant cell development and specifically, the roles of particular cell wall polymers in the establishment of a species-specific shape. For example, what polymer is first produced in the regenerating protoplast? When is cellulose observed and does the deposition of the microfibrils act as the ultimate load bearing component defining cell shape and rigidity? Second, the endomembrane network of Penium is elaborate and trafficking networks have yet to be fully described. Rapid isolation of large amounts of protoplasts will facilitate the isolation and analysis of specific endomembrane components. Finally, protoplasts have become a major means in higher plants to approach questions related to the architectural dynamics of cell wall construction and hybridization [20,96]. Such technology has been successfully used in the moss Physcomitrella patens, where techniques such as somatic hybridization and transformation have been achieved using protoplasts [97-99]. Although not directly related to protoplast research, it is important to notice the observation of Hechtian strands upon plasmolysis of Penium cells (Fig. 3). Their presence was previously described in the green alga Closterium acerosum [100] and the Hechtian Hypothesis has recently been proposed by Lamport et al. This theory suggests Hechtian adhesion to be the first sensor for turgor pressure, which leads to the release of signaling molecules in the cytosol $\left(\mathrm{Ca}^{2+}\right)$ that in turn will lead to an increase of exocytosis of cell wall polymer precursors, causing the extension of the wall [27]. The tight association between Penium polar growth and cell wall deposition [12], and now the observable Hechtian strands make this species a good target for future research regarding this subject.

\section{Conclusion}

In this study we present a simple and effective protocol for isolating protoplasts from the unicellular green alga P. margaritaceum, and describe the use of the protoplasts for imaging subcellular components and membrane microdomains. Furthermore, we describe an optimized protocol for isolating nuclei from protoplasts that can be used to obtain highly pure genomic DNA for subsequent experiments. These methods provide an experimental platform for advancing our understanding of plant cell biology.

\begin{abstract}
Abbreviations
5(6)-CFDA: 5,6-carboxyfluorescein diacetate; AL: adhesive layer; BCECF AM: 2',7'-bis-(2-carboxyethyl)-5,6-carboxyfluorescein, acetoxymethyl ester; BODIPY: boron dipyrromethene 4,4-difluoro-5,7-dimethyl-4-bora-3a,4adiaza-s-indacene; BODIPY ${ }^{\mathrm{TM}}$ FL C5-Ceramide: $n$-(4,4-difluoro-5,7-dimethyl4-bora-3a,4a-diaza-s-indacene-3-pentanoyl) sphingosine; BODIPY ${ }^{\mathrm{TM}} \mathrm{FL}$ $C_{11}$-phosphocholine: 1,2-bis-(4,4-difluoro-5,7-dimethyl-4-bora-3a,4a-diaza-sindacene-3-undecanoyl)-sn-glycero-3-Phosphocholine; CGA: charophycean green algae; CLSM: confocal laser scanning microscopy; DAPI: 4',6-diamidino2-phenylindole; Di-4-ANEPPDHQ: aminonaphthylethenylpyridinium; DIC: differential interference contrast; DiOC6(3): 3,3'-dihexyloxacarbocyanine iodide; EDTA: ethylenediaminetetraacetic acid; EPS: extracellular polysaccharides; ER: endoplasmic reticulum; FM ${ }^{\mathrm{TM}}$ 1-43: N-(3-triethylammoniumpropyl)-4-(4(dibutylamino) styryl) pyridinium dibromide; HG: homogalacturonan; IL: inner layer; mAbs: monoclonal antibodies; ML: middle layer; NIB: nuclei isolation buffer; OL: outer layer; PB: protoplast buffer; PES: protoplast enzyme solution; PL: pectate lyase; RGI: rhamnogalacturonan l; RT: room temperature; TEM: transmission electron microscopy; TRITC: tetramethylrhodamine; WHS: woods hole soil.
\end{abstract}

\section{Authors' contributions}

DSD designed the protocols and performed the TEM; BT and ER supported the development of the protoplast isolation protocol; IS developed and optimized the DNA isolation protocol and downstream quality assessment; SCR optimized the protocols and conducted the research; SCR and DSD analyzed the data and wrote the manuscript. All authors read and approved the final manuscript.

\section{Author details}

${ }^{1}$ Department of Biology, and Skidmore Microscopy Imaging Center, Skidmore College, Saratoga Springs, NY 12866, USA. ${ }^{2}$ Plant Biology Section, School of Integrative Plant Science, Cornell University, Ithaca, NY 14853, USA. ${ }^{3}$ Present Address: Plant Biology, University of Vermont, Burlington, VT 05405, USA.

\section{Acknowledgements}

We thank Dr. Marie-Christine Ralet (INRA, Nantes, France) for kindly providing the INRA-RU1 mAb, and the Genomics Facility of Cornell University's Biotechnology Resource Center (Institute of Biotechnology).

\section{Competing interests}

The authors declare that they have no competing interests.

\section{Consent for publication}

Not applicable.

Ethics approval and consent to participate

Not applicable.

\section{Funding}

This work was supported by NSF Grants NSF-MCB-RUI-1517345, MCB-RUI 0919925 and NSF-MRI-0922805.

\section{Publisher's Note}

Springer Nature remains neutral with regard to jurisdictional claims in published maps and institutional affiliations.

Received: 22 November 2017 Accepted: 15 February 2018

Published online: 24 February 2018 


\section{References}

1. Leliaert F, Smith DR, Moreau H, Herron MD, Verbruggen $H$, Delwiche CF, De Clerck O. Phylogeny and molecular evolution of the green algae. Crit Rev Plant Sci. 2012;31:1-46.

2. Lewis LA, McCourt RM. Green algae and the origin of land plants. Am J Bot. 2004;91:1535-56.

3. Becker B, Marin B. Streptophyte algae and the origin of embryophytes. Ann Bot. 2009;103:999-1004.

4. Delwiche CF, Cooper ED. The evolutionary origin of a terrestrial flora. Curr Biol. 2015;25:R899-910.

5. Timme RE, Bachvaroff TR, Delwiche CF. Broad phylogenomic sampling and the sister lineage of land plants. PLOS ONE. 2012;7:1-8.

6. Domozych DS. Penium margaritaceum: a unicellular model organism for studying plant cell wall architecture and dynamics. Plants. 2014;3:543-58.

7. Rydahl MG, Fangel JU, Mikkelsen MD, Johansen IE, Andreas A, Harholt J, Ulvskov P, Jørgensen B, Domozych DS, Willats WGT. Penium margaritaceum as a model organism for cell wall analysis of expanding plant cells. In: Estevez J, editor. Plant cell expansion. Methods in molecular biology (methods and protocols), vol. 1242. New York: Humana Press; 2015. p. 1-2.

8. Sørensen I, Rose JKC, Doyle JJ, Domozych DS, Willats WGT. The Charophycean green algae as model systems to study plant cell walls and other evolutionary adaptations that gave rise to land plants. Plant Signal Behav. 2012;7:1-3.

9. Worden N, Esteve VE, Domozych DS, Drakakaki G. Using chemical genomics to study cell wall formation and cell growth in Arabidopsis thaliana and Penium margaritaceum. In: Estevez J, editor. Plant cell expansion. Methods in molecular biology (methods and protocols), vol. 1242., Humana PressNY: New York; 2015. p. 23-39.

10. Sørensen I, Pettolino FA, Bacic A, Ralph J, Lu F, O’Neill MA, Fei Z, Rose JKC, Domozych DS, Willats WGT. The charophycean green algae provide insights into the early origins of plant cell walls. Plant J. 2011;68:201-11.

11. Domozych DS, Serfis A, Kiemle SN, Gretz MR. The structure and biochemistry of charophycean cell walls: I. Pectins of Penium margaritaceum. Protoplasma. 2007;230:99-115.

12. Domozych DS, Lambiasse L, Kiemle SN, Gretz MR. Cell-wall development and bipolar growth in the desmid Penium margaritaceum (Zygnematophyceae, Streptophyta). Asymmetry in a symmetric world. J Phycol. 2009;45:879-93.

13. Domozych DS. Exopolymer production by the green alga Penium margaritaceum: implications for biofilm residency. Int J Plant Sci. 2007;168:763-74

14. Domozych DS, Kort S, Benton S, Yu T. The extracellular polymeric substance of the green alga Penium margaritaceum and its role in biofilm formation. Biofilms. 2005:2:129-44.

15. Domozych DS, Sørensen I, Popper ZA, Ochs J, Andreas A, Fangel JU, Pielach A, Sacks C, Brechka H, Ruisi-Besares P, et al. Pectin metabolism and assembly in the cell wall of the Charophyte green alga Penium margaritaceum. Plant Physiol. 2014;165:105-18.

16. Sørensen I, Fei Z, Andreas A, Willats WGT, Domozych DS, Rose JKC. Stable transformation and reverse genetic analysis of Penium margaritaceum: a platform for studies of charophyte green algae, the immediate ancestors of land plants. Plant J. 2014;77:339-51.

17. Ochs J, LaRue T, Tinaz B, Yongue C, Domozych DS. The cortical cytoskeletal network and cell-wall dynamics in the unicellular charophycean green alga Penium margaritaceum. Ann Bot. 2014;114:1237-49.

18. Domozych DS, Sørensen I, Sacks C, Brechka H, Andreas A, Fangel JU, Rose JKC, Willats WGT, Popper ZA. Disruption of the microtubule network alters cellulose deposition and causes major changes in pectin distribution in the cell wall of the green alga, Penium margaritaceum. J Exp Bot. 2014;65:465-79.

19. Cocking EC. Plant cell protoplasts-isolation and development. Annu Rev Plant Physiol. 1972;23:29-50.

20. Eeckhaut T, Lakshmanan PS, Deryckere D, Van Bockstaele E, Van Huylenbroeck J. Progress in plant protoplast research. Planta. 2013;238:991-1003.

21. Davey MR, Anthony P, Power JB, Lowe KC. Plant protoplasts: status and biotechnological perspectives. Biotechnol Adv. 2005;23:131-71.

22. Berliner MD, Wenc KA. Protoplast induction in Micrasterias and Cosmarium. Protoplasma. 1976;89:389-93.
23. Berliner MD. Protoplasts of eukaryotic algae. Int Rev Cytol. 1981;73:1-20

24. Nichols HW. Growth media-freshwater. In: Stein JR, editor. Handbook of phycological methods: culture methods and growth measurements. New York: Cambridge University Press; 1973. p. 39-78.

25. Domozych DS, Lietz A, Patten M, Singer E, Tinaz B, Raimundo SC. Imaging the dynamics of cell wall polymer deposition in the unicellular model plant, Penium margaritaceum. In: Markaki Y, Harz H, editors. Light microscopy: methods and protocols. New York: Springer; 2017. p. 91-105.

26. Fields SD, Strout GW, Russell SD. Spray-freezing freeze substitution (SFFS) of cell suspensions for improved preservation of ultrastructure. Microsc Res Techn. 1997;38:315-28.

27. Lamport DTA, Tan L, Held M, Kieliszewski MJ. Pollen tube growth and guidance: Occam's razor sharpened on a molecular arabinogalactan glycoprotein Rosetta Stone. New Phytol. 2017;217:491-500.

28. Clausen MH, Willats WGT, Knox JP. Synthetic methyl hexagalacturonate hapten inhibitors of anti-homogalacturonan monoclonal antibodies LM7, JIM5 and JIM7. Carbohydr Res. 2003:338:1797-800.

29. Ralet M-C, Tranquet O, Poulain D, Moïse A, Guillon F. Monoclonal antibodies to rhamnogalacturonan I backbone. Planta. 2010;231:1373-83.

30. Van Alebeek G-JWM, Christensen TMIE, Schols HA, Mikkelsen JD, Voragen AGJ. Mode of action of pectin lyase A of Aspergillus nigeron differently C6-substituted oligogalacturonides. J Biol Chem. 2002;277:25929-36.

31. Han J, Burgess K. Fluorescent indicators for intracellular pH. Chem Rev. 2010;110:2709-28.

32. Swanson SJ, Choi W-G, Chanoca A, Gilroy S. In vivo imaging of $\mathrm{Ca}^{2+}, \mathrm{pH}$ and reactive oxygen species using fluorescent probes in plants. Annu Rev Plant Biol. 2011;62:273-97.

33. O'Connor N, Silver RB. Ratio imaging: practical considerations for measuring intracellular $\mathrm{Ca}^{2+}$ and $\mathrm{pH}$ in living cells. In: Sluder $\mathrm{G}$, editor. Methods in cell biology, vol. 114. Wolf DE: Academic Press; 2013. p. 387-406.

34. Gdovin MJ, Zamora DA, Ravindran CRM, Leiter JC. Optical recording of intracellular $\mathrm{pH}$ in respiratory chemoreceptors. Ethn Dis. 2010;20:S1-8-S33-8.

35. Pasternak TP, Prinsen E, Ayaydin F, Miskolczi P, Potters G, Asard H, Van Onckelen HA, Dudits D, Fehér A. The role of auxin, $\mathrm{pH}$, and stress in the activation of embryogenic cell division in leaf protoplast-derived cells of alfalfa. Plant Physiol. 2002;129:1807-19.

36. Bush DS, Jones RL. Measurement of cytoplasmic calcium in aleurone protoplasts using indo-1 and fura-2. Cell Calcium. 1987:8:455-72.

37. Swanson SJ, Jones RL. Gibberellic acid induces vacuolar acidification in Barley aleurone. Plant Cell. 1996:8:2211-21.

38. D'Onofrio C, Lindberg S. Sodium induces simultaneous changes in cytosolic calcium and $\mathrm{pH}$ in salt-tolerant quince protoplasts. J Plant Physiol. 2009;166:1755-63.

39. Gupta A, Bhatla SC. Spatial and temporal changes in lipase activity sites during oil body mobilization in protoplasts from sunflower seedling cotyledons. Plant Growth Regul. 2005;46:11-7.

40. Gupta A, Sadeghipour HR, Bhatla SC. Subcellular detection of lipase activity in plant protoplasts using fluorescence microscopy. Plant Growth Regul. 2003;41:259-64.

41. Hatsugai N, Kuroyanagi M, Yamada K, Meshi T, Tsuda S, Kondo M, Nishimura M, Hara-Nishimura I. A plant vacuolar protease, VPE, mediates virus-induced hypersensitive cell death. Science. 2004;305:855-8.

42. Blatt MR, Beilby MJ. Mitochondrial sequestration of BCECF after ester loading in the giant alga Chara australis. Protoplasma. 2007;232:131-6.

43. Hoefel D, Grooby WL, Monis PT, Andrews S, Saint CP. A comparative study of carboxyfluorescein diacetate and carboxyfluorescein diacetate succinimidyl ester as indicators of bacterial activity. J Microbiol Methods. 2003:52:379-88.

44. McGinnes K, Chapman G, Marks R, Penny R. A fluorescence NK assay using flow cytometry. J Immunol Methods. 1986;86:7-15.

45. Li J, Kuang Y, Shi J, Zhou J, Medina JE, Zhou R, Yuan D, Yang C, Wang H, Yang Z, et al. Enzyme-instructed intracellular molecular self-assembly to boost activity of cisplatin against drug-resistant ovarian cancer cells. Angew Chem Int Ed. 2015:54:13307-11.

46. Hafke JB, Furch ACU, Reitz MU, van Bel AJE. Functional sieve element protoplasts. Plant Physiol. 2007;145:703-11. 
47. Schulz A, Knoetzel J, Scheller HV, Mant A. Uptake of a fluorescent dye as a swift and simple indicator of organelle Intactness: import-competent chloroplasts from soil-grown Arabidopsis. J Histochem Cytochem. 2004;52:701-4.

48. Fotopoulos V. Never say dye: new roles for an old fluorochrome. Plant Signal Behav. 2012;7:342-4.

49. Foissner I, Menzel D, Wasteneys GO. Microtubule-dependent motility and orientation of the cortical endoplasmic reticulum in elongating characean internodal cells. Cell Motil Cytoskelet. 2009;66:142-55.

50. Terasaki M, Chen LB, Fujiwara K. Microtubules and the endoplasmic reticulum are highly interdependent structures. J Cell Biol. 1986;103:1557-68.

51. Terasaki M, Song J, Wong JR, Weiss MJ, Chen LB. Localization of endoplasmic reticulum in living and glutaraldehyde-fixed cells with fluorescent dyes. Cell. 1984;38:101-8.

52. Kawazu T, Kawano S, Kuroiwa T. Distribution of the Golgi apparatus in the mitosis of cultured tobacco cells as revealed by DiOC6 fluorescence microscopy. Protoplasma. 1995:186:183-92.

53. Koning AJ, Lum PY, Williams JM, Wright R. DiOC6 staining reveals organelle structure and dynamics in living yeast cells. Cell Motil Cytoskelet. 1993;25:111-28

54. Otegui MS, Noh Y-S, Martínez DE, Vila Petroff MG, Andrew Staehelin L, Amasino RM, Guiamet JJ. Senescence-associated vacuoles with intense proteolytic activity develop in leaves of Arabidopsis and soybean. The Plant Journal. 2005;41:831-44.

55. Álvarez C, García I, Moreno I, Pérez-Pérez ME, Crespo JL, Romero LC, Gotor C. Cysteine-generated sulfide in the cytosol negatively regulates autophagy and modulates the transcriptional profile in Arabidopsis. Plant Cell. 2012:24:4621-34.

56. Farage-Barhom S, Burd S, Sonego L, Mett A, Belausov E, Gidoni D, Lers A. Localization of the Arabidopsis senescence- and cell deathassociated BFN1 nuclease: from the ER to fragmented nuclei. Mol Plant. 2011:4:1062-73.

57. Kang YW, Jeon Y, Pai H-S. Characterization of cell death induced by NbBPS1 silencing in Nicotiana benthamiana. Mol Cells. 2012;34:185-91.

58. Cole L, Orlovich DA, Ashford AE. Structure, function, and motility of vacuoles in filamentous fungi. Fungal Genet Biol. 1998;24:86-100.

59. Abrahams S, Lee E, Walker AR, Tanner GJ, Larkin PJ, Ashton AR. The Arabidopsis TDS4 gene encodes leucoanthocyanidin dioxygenase (LDOX) and is essential for proanthocyanidin synthesis and vacuole development. Plant J. 2003;35:624-36.

60. Wiltshire EJ, Collings DA. New dynamics in an old friend: dynamic tubular vacuoles radiate through the cortical cytoplasm of red onion epidermal cells. Plant Cell Physiol. 2009:50:1826-39.

61. Scheuring D, Schöller M, Kleine-Vehn J, Löfke C. Vacuolar staining methods in plant cells. In: Estevez JM, editor. Plant cell expansion: methods and protocols. New York: Springer; 2015. p. 83-92.

62. Simons K, Gerl MJ. Revitalizing membrane rafts: new tools and insights. Nat Rev Mol Cell Biol. 2010;11:688-99.

63. Simons K, Vaz WL. Model systems, lipid rafts, and cell membranes. Annu Rev Biophys Biomol Struct. 2004;33:269-95.

64. Pagano RE, Martin OC, Kang HC, Haugland RP. A novel fluorescent ceramide analogue for studying membrane traffic in animal cells: accumulation at the Golgi apparatus results in altered spectral properties of the sphingolipid precursor. J Cell Biol. 1991;113:1267-79.

65. Butler CE, Wheeler G, Graham J, Tyler KM. Visual discrimination of membrane domains in live cells by widefield microscopy. In: Mély Y, Duportail $\mathrm{G}$, editors. Fluorescent methods to study biological membranes, vol. 13. Berlin: Springer; 2012. p. 163-84.

66. Marks DL, Bittman R, Pagano RE. Use of Bodipy-labeled sphingolipid and cholesterol analogs to examine membrane microdomains in cells. Histochem Cell Biol. 2008;130:819-32.

67. Klymchenko AS, Kreder R. Fluorescent probes for lipid rafts: from model membranes to living cells. Chem Biol. 2014;21:97-113.

68. Blachutzik JO, Demir F, Kreuzer I, Hedrich R, Harms GS. Methods of staining and visualization of sphingolipid enriched and non-enriched plasma membrane regions of Arabidopsis thaliana with fluorescent dyes and lipid analogues. Plant Methods. 2012:8:1-17.

69. Lisboa S, Scherer GEF, Quader H. Localized endocytosis in tobacco pollen tubes: visualisation and dynamics of membrane retrieval by a fluorescent phospholipid. Plant Cell Rep. 2008;27:21-8.
70. Foissner I. Fluorescent phosphocholine-a specific marker for the endoplasmic reticulum and for lipid droplets in Chara internodal cells. Protoplasma. 2009;238:47-58.

71. Martin OC, Pagano RE. Internalization and sorting of a fluorescent analogue of glucosylceramide to the Golgi apparatus of human skin fibroblasts: utilization of endocytic and nonendocytic transport mechanisms. J Cell Biol. 1994;125:769-81.

72. Singh RD, Puri V, Valiyaveettil JT, Marks DL, Bittman R, Pagano RE. Selective caveolin-1 - dependent endocytosis of glycosphingolipids. Mol Biol Cell. 2003;14:3254-65.

73. Watanabe R, Asakura K, Rodriguez M, Pagano R. Internalization and sorting of plasma membrane sphingolipid analogues in differentiating oligodendrocytes. J Neurochem. 1999;73:1375-83.

74. Chazotte B. Labeling the Golgi apparatus with BODIPY-FL-ceramide (C5-DMB-ceramide) for imaging. Cold Spring Harbor Protocols. 2008. 2008:prot4931.

75. Amaro M, Reina F, Hof M, Eggeling C, Sezgin E. Laurdan and Di-4-ANEPPDHQ probe different properties of the membrane. J Phys D Appl Phys. 2017;50:1-9.

76. Jin L, Millard AC, Wuskell JP, Dong X, Wu D, Clark HA, Loew LM. Characterization and application of a new optical probe for membrane lipid domains. Biophys J. 2006:90:2563-75.

77. Jin L, Millard AC, Wuskell JP, Clark HA, Loew LM. Cholesterol-enriched lipid domains can be visualized by di-4-ANEPPDHQ with linear and nonlinear optics. Biophys J. 2005;89:LO4-6.

78. Simons K, Ikonen E. Functional rafts in cell membranes. Nature. 1997:387:569-72.

79. Betz WJ, Mao F, Bewick GS. Activity-dependent fluorescent staining and destaining of living vertebrate motor nerve terminals. J Neurosci. 1992;12:363-75

80. Betz WJ, Mao F, Smith CB. Imaging exocytosis and endocytosis. Curr Opin Neurobiol. 1996;6:365-71.

81. Fischer-Parton S, Parton RM, Hickey PC, Dijksterhuis J, Atkinson HA, Read ND. Confocal microscopy of FM4-64 as a tool for analysing endocytosis and vesicle trafficking in living fungal hyphae. J Microsc. 2000;198:246-59.

82. Bolte S, Talbot C, Boutte Y, Catrice O, Read ND, Satiat-Jeunemaitre B. FMdyes as experimental probes for dissecting vesicle trafficking in living plant cells. J Microsc. 2004;214:159-73.

83. Kuromi H, Kidokoro Y. Exocytosis and endocytosis of synaptic vesicles and functional roles of vesicle pools: lessons from the Drosophila neuromuscular junction. Neuroscientist. 2005:11:138-47.

84. Amaral E, Guatimosim S, Guatimosim C. Using the fluorescent styryl dye FM1-43 to visualize synaptic vesicles exocytosis and endocytosis in motor nerve terminals. In: Chiarini-Garcia H, Melo RCN, editors. Light microscopy: methods in molecular biology. Totowa: Humana Press; 2011. p. 137-48.

85. Parton RM, Fischer-Parton S, Watahiki MK, Trewavas AJ. Dynamics of the apical vesicle accumulation and the rate of growth are related in individual pollen tubes. J Cell Sci. 2001;114:2685-95.

86. Vida TA, Emr SD. A new vital stain for visualizing vacuolar membrane dynamics and endocytosis in yeast. J Cell Biol. 1995;128:779-92.

87. Rigal A, Doyle SM, Robert S. Live cell imaging of FM4-64, a tool for tracing the endocytic pathways in Arabidopsis root cells. In: Estevez JM, editor. Plant cell expansion: methods and protocols. New York: Springer; 2015. p. 93-103.

88. Kubitscheck U, Homann U, Thiel G. Osmotically evoked shrinking of guard-cell protoplasts causes vesicular retrieval of plasma membrane into the cytoplasm. Planta. 2000;210:423-31.

89. Emans N, Zimmermann S, Fischer R. Uptake of a fluorescent marker in plant cells is sensitive to brefeldin A and wortmannin. Plant Cell. 2002;14:71-86.

90. Camacho L, Malhó R. Endo/exocytosis in the pollen tube apex is differentially regulated by $\mathrm{Ca}^{2+}$ and GTPases. J Exp Bot. 2003;54:83-92.

91. Klima A, Foissner I. FM dyes label sterol-rich plasma membrane domains and are internalized independently of the cytoskeleton in characean internodal cells. Plant Cell Physiol. 2008;49:1508-21.

92. Foissner I, Klima A. Constitutive endocytosis in characean internodal cells is independent of an intact actin cytoskeleton. Cell Biol Int. 2008:32:579-80. 
93. Ohyama K, Pelcher LE, Horn D. A rapid, simple method for nuclei isolation from plant protoplasts. Plant Physiol. 1977;60:179-81.

94. Saxena PK, Fowke LC, King J. An efficient procedure for isolation of nuclei from plant protoplasts. Protoplasma. 1985;128:184-9.

95. Sikorskaite S, Rajamäki M-L, Baniulis D, Stanys V, Valkonen JPT. Protocol: optimised methodology for isolation of nuclei from leaves of species in the Solanaceae and Rosaceae families. Plant Methods. 2013;9:1-9.

96. Yokoyama R, Kuki H, Kuroha T, Nishitani K. Arabidopsis regenerating protoplast: a powerful model system for combining the proteomics of cell wall proteins and the visualization of cell wall dynamics. Proteomes. 2016;4:1-15.

97. Cove DJ, Perroud P-F, Charron AJ, McDaniel SF, Khandelwal A, Quatrano RS. Isolation and regeneration of protoplasts of the moss Physcomitrella patens. Cold Spring Harbor Protocols. 2009. 2009:pdb.prot5140.
98. Cove DJ, Perroud P-F, Charron AJ, McDaniel SF, Khandelwal A, Quatrano RS. Somatic hybridization in the moss Physcomitrella patens using PEG-induced protoplast fusion. Cold Spring Harbor Protocols. 2009. 2009:pdb.prot5141.

99. Cove DJ, Perroud P-F, Charron AJ, McDaniel SF, Khandelwal A, Quatrano RS. Transformation of the moss Physcomitrella patens using Ddirect DNA uptake by protoplasts. Cold Spring Harbor Protocols. 2009. 2009:pdb. prot5143.

100. Domozych DS, Roberts R, Danyow C, Flitter R, Smith B, Providence K. Plasmolysis, hechtian strand formation, and localized membrane-wall adhesions in the desmid, Closterium acerosum (Chlorophyta). J Phycol. 2003;39:1194-206.

\section{Submit your next manuscript to BioMed Central and we will help you at every step:}

- We accept pre-submission inquiries

- Our selector tool helps you to find the most relevant journal

- We provide round the clock customer support

- Convenient online submission

- Thorough peer review

- Inclusion in PubMed and all major indexing services

- Maximum visibility for your research

Submit your manuscript at www.biomedcentral com/submit 